\title{
Normal Development: The Photographic Dome and the Children of the Yale Psycho-Clinic
}

\author{
Carola Ossmer, Leuphana University of Lüneburg
}

\begin{abstract}
This essay traces the history of normality's development through a photographic research program that itself began with a critique of that very concept. In the 1920s, a group of child development researchers around the psychologist and physician Arnold Gesell constructed the photographic dome-at once laboratory, observatory, and film studioto assess normal mental development. Although seeking to challenge standardized measurements of the normal, the researchers created a set of developmental norms that shaped a universal understanding of what constituted a normal child. This essay examines the foundation of this pervasive knowledge by tracking the material factors of visual technology and media production: organizing scientific research like film production, Gesell and his team began to think of development in photographic sequences. Film technology configured their ideas about the individuality of every child, gave rise to a democratic variety of norms, and linked the scientific laboratory with private households and public life. The essay thus argues that visual technologies, beyond merely providing a scientific method and a means of popular distribution, constituted far-reaching theories regarding the normal child. This media-material perspective demonstrates that focusing on visual technologies in science can help to denaturalize knowledge about human nature.
\end{abstract}

$\mathrm{H}$ dward Calhoun entered the dome-shaped steel construction in the arms of his mother. 1 She placed him, naked, in a crib next to an old man in white who called him Teddy. His mother left him in the brightly lit room with the mumbling man. Mrs. Calhoun, standing as close

Carola Ossmer is a researcher in the history of knowledge at the Leuphana University of Lüneburg. Her research explores how perceptions of development and normality are entangled with the histories of the human sciences and media technologies. Institute of History and Literary Cultures, Leuphana University of Lüneburg, Universitätsallee 1, 21335 Lüneburg, Germany; carola.ossmer@leuphana.de.

Acknowledgments. For generous critique and conversations, I would like to thank Cornelius Borck, Jamie Cohen-Cole, Lorraine Daston, Nick Hopwood, Verena Lehmbrock, Linda Mayes, Christine von Oertzen, Barbara Pohl, Laurens Schlicht, Susanne Schmidt, Thomas Sturm, Christina Wessely, the participants in the Colloquium for the History of Medicine at the Universität zu Lübeck, the Forum Geschichte der Humanwissenschaften, and the Holmes Workshop at Yale University. In particular, I would like to thank Henry Cowles, who made invaluable contributions to all versions of the manuscript, and the anonymous referees for their many helpful comments and suggestions. Work on this essay wouldn't have been possible without the support of the archivists and librarians of the Library of Congress, the Yale University Libraries and Archives, the Cummings Center for the History of Psychology, and the Rockefeller Archive Center, as well as funding from the Rockefeller Archive Center, the Heinrich-Böll-Stiftung, and the Max Planck Institute for the History of Science (Dept. II/Daston). 
as possible behind a one-way-vision segregation screen, was nervous and excited. And she was not alone. She watched her four-week-old son along with clinical observers and two cameras as, on 17 May 1927, Teddy became one of the first babies to participate in a new experimental study about normal infancy. She and Teddy had gotten involved when her nurse asked whether she was interested in participating in the study. Though she hesitated at first-one had to be careful with such things - Mrs. Calhoun's faith in so-called scientific child-rearing trumped her wariness. The scientists had explained how Teddy, with her help, would contribute to the progress not just of science but of society too. Now Teddy played-or, rather, he tried to. He was too focused on the toys in the crib to fret about his mother's absence. Mrs. Calhoun thought her son did well, as did the doctor and the other researchers. They turned Teddy into a "normal growth case" and made him the first trial subject in a novel photographic research program. The question the researchers wanted Teddy to answer was: How can an infant reveal the law of normal mental development? ${ }^{1}$

This research scene was central to the formation of developmental norms that would shape a universal understanding of what constituted a normal child. Simultaneously situated in science and society, norms of child development were an early indication of a broader notion of normality still to come. Historical accounts of the concept of normality have highlighted that before the twentieth century the normal was an analytical companion to the pathological or deviant, rather than a stand-alone phenomenon. Over the course of the twentieth century, normality gained its own status as a desirable ideal for the general public. The research conducted on Teddy was part of a concerted effort to make this ideal a reality. After the Great War, political reformers, medical practitioners, and scientific researchers all turned to issues of normality. ${ }^{2}$ Both the normal and the child were understood to be key to the prosperous and democratic future of the nation, and in the 1920s the study of normal (rather than pathological) children was promoted with zeal. In order to facilitate the normality of future citizens, the nascent science of child development was sent on a collective quest for developmental data. ${ }^{3}$ This emerging field included a group of scientists at the Yale Psycho-Clinic, where Baby Teddy was soon providing data for the study of

\footnotetext{
${ }^{1}$ The following archival collections and archival sources, many of which have never been explored in any publication, have been invaluable in writing this paper, as well as in establishing the scene just described. These include the Archives of the History of American Psychology, Cummings Center for the History of Psychology, University of Akron (hereafter CCHP), Arnold Gesell film collection, index card catalogue of the Photographic Research Library; the Library of Congress, Washington, D.C., Manuscript Division, Arnold Gesell Papers (hereafter Gesell Papers), Box 129, Notes of Staff Meetings; and the Rockefeller Archive Center, Laura Spelman Rockefeller Memorial records, FA061 (hereafter LSRM), Series 3.5, Box 47, Folders 492 and 493, Reports from Yale to the LSRM. Information about the introductory scene was also taken from Arnold Gesell, Infancy and Human Growth (New York: Macmillan, 1928) (hereafter cited as Gesell, Infancy and Human Growth); Gesell and Helen Thompson, Infant Behavior: Its Genesis and Growth (New York: McGraw-Hill, 1934); and Gesell and Thompson, The Psychology of Early Growth (New York: Macmillan, 1938).

${ }^{2}$ For a synthesis of the history of twentieth-century normality see Peter M. Cryle and Elizabeth Stephens, Normality: A Critical Genealogy (Chicago: Univ. Chicago Press, 2017). On constructions of the normal see also Ian Hacking, The Taming of Chance (Cambridge: Cambridge Univ. Press, 1990); Jürgen Link, Versuch über den Normalismus: Wie Normalität produziert wird (Opladen: Westdeutscher, 1997); Georges Canguilhem, The Normal and the Pathological (1943), 4th ed. (New York: Zone, 1991); and, especially in the context of the U.S. social sciences, Sarah Elizabeth Igo, The Averaged American: Surveys, Citizens, and the Making of a Mass Public (Cambridge, Mass.: Harvard Univ. Press, 2007).

${ }^{3}$ On the shift to the normal in child development research see Alice Boardman Smuts, Science in the Service of Children, 1893 1935 (New Haven, Conn.: Yale Univ. Press, 2006), pp. 117-172; and Hamilton Cravens, Before Head Start: The Iowa Station and America's Children (Chapel Hill: Univ. North Carolina Press, 1993), pp. 27-29. On histories of developmental psychology see Robert B. Cairns and Beverly D. Cairns, "The Making of Developmental Psychology," in Handbook of Child Psychology, ed. Richard M. Lerner and William Damon, 6th ed. (Hoboken, N.J.: Wiley, 2006), pp. 89-165; and Dennis Thompson, John D. Hogan, and Philip M. Clark, Developmental Psychology in Historical Perspective (Malden, Mass.: Wiley-Blackwell, 2012).
} 
normal mental development. By the end of their research project, the Yale researchers had created a set of norms - also known as developmental milestones - that would become a worldwide standard for assessing a child's normality. ${ }^{4}$

This essay traces the history of normality's development through a research program that began, ironically, with a critique of that very concept. The Yale Juvenile Psycho-Clinic, where the research project on normal mental development was situated, was founded in 1911 by the educator, psychologist, and physician Arnold Lucius Gesell. In 1918 Gesell expanded the activities of the clinic, initially a service center for the study and counseling of "retarded" children, to include investigations of the normal child. ${ }^{5}$ However, no single "normal" existed. Whereas health workers thought of the normal in terms of the absence of illness - a state they strove to preservesocial reformers and public opinion makers were interested in a notion of normality that could be applied to the U.S. population as a whole. Scientists, in turn, constructed normality mostly by calculating statistical averages from data. Gesell criticized this as a misperception, cautioning against the mediocrity of an averaged normal and questioning a methodology based on the numerical scales prevalent in psychological testing. Children could not be captured by averages or pictured in numbers, he insisted, but needed to be inspected on a case-by-case basis. ${ }^{6}$ Gesell and his team at the Psycho-Clinic came up with unique means of doing just that, innovating photographic and film techniques in order to collect, interpret, and transmit unaveraged data of normal mental development. These visual technologies differed from prevailing methods of measurement while adhering to scientific standards and increasing the public utility of developmental data. Or at least this was what Gesell and his team imagined.

Historians and developmental psychologists have presented Gesell as an originator of developmental norms. In the form of diagnostic schedules, child-rearing books, and educational films, these norms provided a "timetable of development" for professionals and parents, promoting a form of management of normal child development by milestones that is still commonplace today. ${ }^{7}$ Among the few scholars who have researched Gesell's work, Ellen Herman has insightfully

\footnotetext{
${ }^{4}$ The books of the Yale Psycho-Clinic team were translated for global use into Chinese, Japanese, Russian, Spanish for Latin America, and several European languages, including German, French, and Italian. The Gesell norms are still included in pediatric textbooks-e.g., Georg F. Hoffmann et al., Pädiatrie: Grundlagen und Praxis (Berlin: Springer, 2014). For their dominance in the United States see Ann Hulbert, Raising America: Experts, Parents, and a Century of Advice about Children (New York: Knopf, 2003); and Julia Grant, Raising Baby by the Book: The Education of American Mothers (New Haven, Conn.: Yale Univ. Press, 1998).

5 "Yale Juvenile Psycho-Clinic" was the official founding title; the juveniles disappeared from title and program soon after the clinic was put into operation. See Arnold Gesell, "Autobiography," in A History of Psychology in Autobiography, Vol. 4, ed. Edwin G. Boring et al. (Worcester, Mass.: Clark Univ. Press, 1952), pp. 123-143; and Frederic Weizmann and Ben Harris, "Arnold Gesell: The Maturationist," in Portraits of Pioneers in Developmental Psychology, ed. Wade E. Pickren, Donald A. Dewsbury, and Michael Wertheimer (New York: Psychology, 2012), pp. 1-20.

${ }^{6}$ Gesell's practical opposition to common conceptions of the normal becomes clearer in light of Georges Canguilhem's evaluation of the normal and the pathological from 1943, especially the critique of the thesis of nineteenth-century physiology that "pathological phenomena are identical to corresponding normal phenomena save for quantitative variations": Canguilhem, Normal and the Pathological (cit. n. 2), p. 35. See Arnold Gesell and Beatrice Chandler Gesell, The Normal Child and Primary Education (Boston: Ginn, 1912), esp. pp. vi, viii; Gesell, The Mental Growth of the Pre-School Child (New York: Macmillan, 1925); and Arnold Gesell to Thomas Yerkes, 16 Mar. 1922, Gesell Papers, Box 91. For the normal in the 1920s see Igo, Averaged American (cit. n. 2).

${ }^{7}$ For ongoing discussions about Gesell's psychology and legacy see Karen Adolph and Esther Thelen, "Arnold L. Gesell: The Paradox of Nature and Nurture," Developmental Psychology, 1992, 28:368-380; Frank J. Marchese, "The Place of Eugenics in Arnold Gesell's Maturation Theory of Child Development," Canadian Psychology, 1995, 36:89-114; Grant, Raising Baby by the Book (cit. n. 4); Ellen Herman, "Families Made by Science: Arnold Gesell and the Technologies of Modern Child Adoption," Isis, 2001, 92:684-715; Hulbert, Raising America (cit. n. 4); Thomas C. Dalton, "Arnold Gesell and the Maturation Controversy," Integrative Physiological and Behavioral Science, 2005, 40:182-204; Smuts, Science in the Service of Children (cit. n. 3), pp. 173190; Frederic Weizmann, "From the 'Village of a Thousand Souls' to 'Race Crossing in Jamaica': Arnold Gesell, Eugenics, and
} 
illustrated the regulatory force and normative power of the developmental norms once they had come into widespread use. ${ }^{8}$ The significance of film and photography for the developmental research and its distribution has been addressed in a few historical studies. Some of these have focused on the visual methods of studying development, pointing at the theoretical correspondence between the concept of successive developmental stages and the successive order of photographic images and moving pictures. Others have criticized the normative visualization of children for having a standardizing effect on childhood. ${ }^{9}$ All these studies have concentrated on Gesell's research methods and the norms once they were well established - that is, when the critical work that went into the conceptualization of normal development had already been done. Although the concept of development and the norms produced at the Yale Psycho-Clinic were highly influential for understandings of mental development and the normal child, remarkably little attention has been paid to their initial formation.

This essay returns to the foundation of this pervasive knowledge: the construction of the photographic dome (see Figure 1). Built between 1926 and 1928, the photographic dome was at once laboratory, observatory, and film studio. Its visual technology was at the core of the research and educational work at the Yale Psycho-Clinic - and, as I will show, a turning point for the researchers' theoretical conception of development and the normal. The purpose here is not to discuss developmental norms as a tool of normalization. I do not analyze images of development, nor do I place the dome into a history of scientific methodology and theory. Instead, I make a case for tracking the material factors of visual technology and studying scientific research in terms of media production: tracing the work of constructing the photographic dome technology and photographic data production aims to detect the mechanism behind the developmental norms and their making. Doing so sheds light on knowledge that was often taken for granted because the visual constitution of child development seemed natural and inevitable; it therefore contributed to an era of normalcy.

As Gesell and his team constructed the photographic dome, they organized their research along the lines of film production and film material. Working with unexplored archival sources from the initial period of the photographic research program, I show in this essay that the material factors of film technology constituted a consequential idea of the mind and development of a normal child: the researchers began to think of development in photographic sequence. Through precise comparisons of a recorded child with her former and future selves, the "photographic sequence record" indicated a continuity of individual development from birth to adulthood. ${ }^{10}$ Seen in the light of film production, even newborns were already individuals with minds of their own. The norms emanating from this conclusion were created as an instrument to measure and foster normality based on free individual development, by contrast to an

Child Development," Journal of the History of the Behavioral Sciences, 2010, 46:263-275; Ben Harris, "Arnold Gesell's Progressive Vision: Child Hygiene, Socialism, and Eugenics," History of Psychology, 2011, 14:311-334; and Scott Curtis, "Tangible as Tissue': Arnold Gesell, Infant Behavior, and Film Analysis," Science in Context, 2011, 24:417-442. "Timetable of development" is taken from Weizmann and Harris, "Arnold Gesell" (cit. n. 5), p. 1.

${ }^{8}$ Herman, "Families Made by Science." See also Nikolas Rose, Inventing Ourselves: Psychology, Power, and Personhood (Cambridge: Cambridge Univ. Press, 1996), pp. 110-111; and Rose, Governing the Soul: The Shaping of the Private Self (London: Routledge, 1989) (the photographic dome is shown on the book cover).

${ }^{9}$ For visual methods and development in Gesell's work see Curtis, “Tangible as Tissue'” (cit. n. 7); and Andrew Lakoff, "Freezing Time: Margaret Mead's Diagnostic Photography," Visual Anthropology Review, 1996, 12:1-18. On embryological visualizations of development see Janina Wellmann, Die Form des Werdens: Eine Kulturgeschichte der Embryologie, 1760-1830 (Göttingen: Wallstein, 2010). On normalization effects see Donna Varga, "Look-Normal: The Colonized Child of Developmental Science," Hist. Psychol., 2011, 14:137-157; André Turmel, A Historical Sociology of Childhood: Developmental Thinking, Categorization, and Graphic Visualization (Cambridge: Cambridge Univ. Press, 2008); and Rose, Governing the Soul.

10 "Photographic sequence record" is Gesell's wording: Notes of Staff Meeting, 29 Oct. 1926, Gesell Papers, Box 129. 


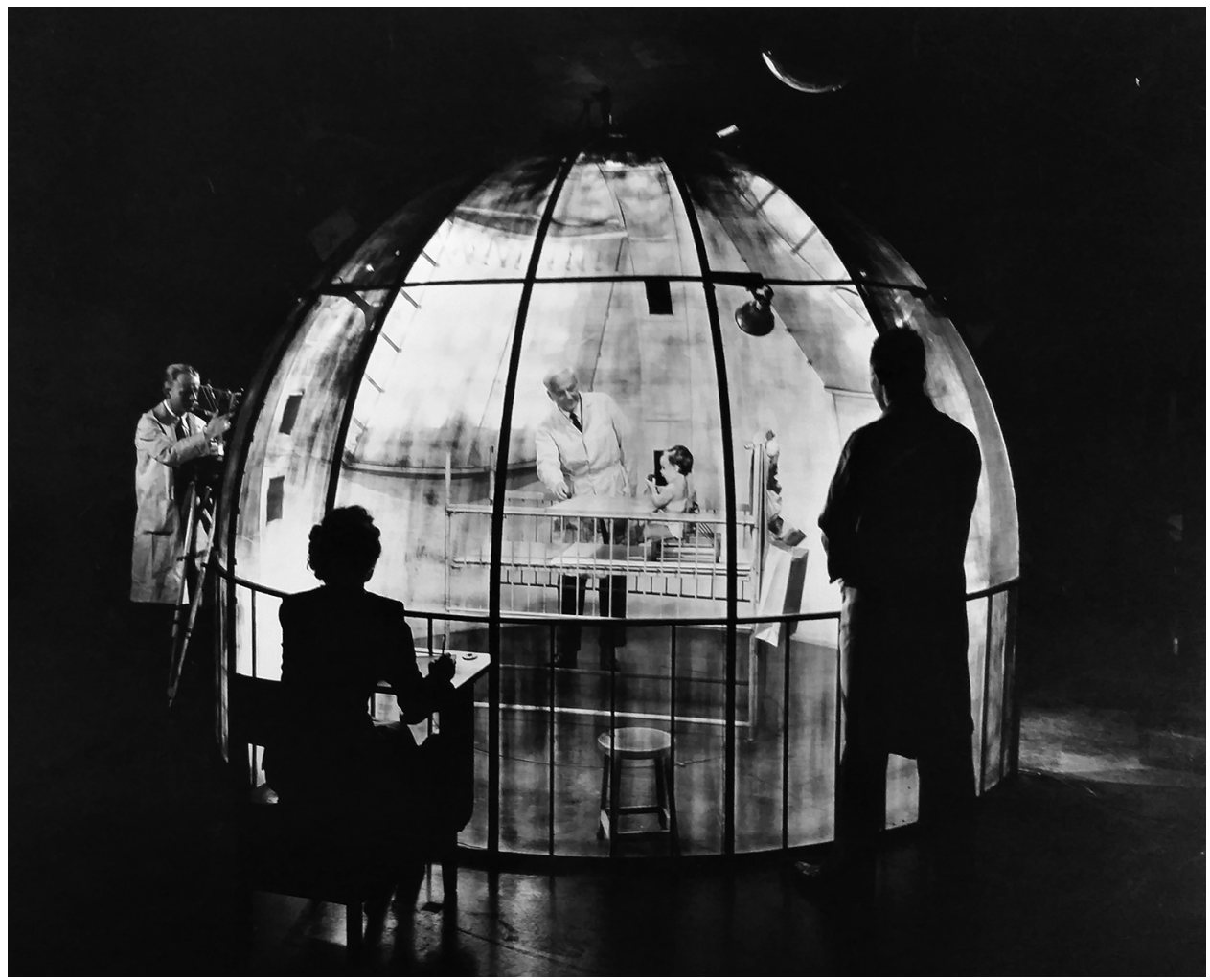

Figure 1. Photographic dome with Gesell and baby, camera operator, stenographer, and clinical observer, in a photo session with the Life Magazine photographer Herbert Gehr in 1947. Image: Historical collection of the Yale Child Study Center (formerly the Yale Psycho-Clinic and then the Yale Clinic of Child Development); reproduced with kind permission of the Yale Child Study Center.

averaged normal of rigid numerical regulation. For Gesell, film production became a technology of individuality in both research and intervention that contributed to a variety of norms he found essential for democracy. The stakes involved in the adoption of visual technology were not just the performance of a scientific method and the intellectual evolution of a scientific theory, nor indeed the ease of popular distribution, but, I argue, the material configuration and constitution of ideas with lasting effects in and outside the laboratory. In other words: to understand the concept and consequences of the developmental norms fully, we must look at the material aspects of their production.

What can historians of science learn by accounting for material factors and, more specifically, visual technology in science? To make the case that revolves around the dome, I bring forward the findings of recent historical investigations on materials of knowledge. As these studies demonstrate, material things - whether objects or instruments - embody ideas. ${ }^{11}$ So too did

\footnotetext{
${ }^{11}$ See Simon Werrett, Thrifty Science: Making the Most of Materials in the History of Experiment (Chicago: Univ. Chicago Press, 2019); Carla Bittel, Elaine Leong, and Christine von Oertzen, eds., Working with Paper: Gendered Practices in the History of Knowledge (Pittsburgh: Univ. Pittsburgh Press, 2019); Werrett, "Matter and Facts: Material Culture in the History of Science," in Material Evidence: Learning from Archaeological Practice, ed. Robert Chapman and Alison Wylie (New York: Routledge, 2014), pp. 339-352; and Lorraine Daston, ed., Things That Talk: Object Lessons from Art and Science (New York: Zone, 2004).
} 
the technology at the Yale Psycho-Clinic that was devised to make normal mental development visible. Studying the material making of visual technologies can reveal underlying theories and ideologies - here, theories and ideologies of development and normality - that were embedded in techno-material constructions and in image production. ${ }^{12}$ As this case study highlights, these materials in turn themselves configured scientific thinking and co-constituted ideas concerning the normal child. ${ }^{13}$ Focusing on material sites of science makes visible the people, interests, and institutions, as well as their relationships and the requisite labor, that were involved in knowledge formation. Once we attend to the material matter behind their visual display, the same goes for the technology behind film production, depicted in the opening scene of this essay as a multilayered arrangement within and around the dome, and for the photographs and films produced. ${ }^{14}$

Visual technologies and film material thus had a double function. Enabling scientific research may have been their primary purpose, but they also enabled intervention. Normal babies and their development could now travel in a lifelike way, enabling those who used such techniques to produce, use, and diffuse knowledge of normal development in laboratories, classrooms, clinics, and the family home. ${ }^{15}$ This second purpose of visualization, wide dissemination, co-defined the research design from the start. Elucidating the simultaneity of data and media production, the study of visual technology thus provides insight into the convergence of scientific research, professional practice, and education and links the scientific laboratory study of the child with private households and public life. In this essay, spotlights on the scientific, social, institutional, and ideological conditions and consequences of the photographic dome technology illuminate the story behind the developmental norms. The essay thus provides a media-material perspective on the history of the sciences of child, mind, and development that adds to historical understanding of the twentieth-century notion of normality. In the end, such a focus on visual technologies in the history of science can help to denaturalize what had come

\footnotetext{
${ }^{12}$ For film technology this has been aptly shown by Scott Curtis, The Shape of Spectatorship: Art, Science, and Early Cinema in Germany (New York: Columbia Univ. Press, 2015). On a more photographic setting see Kelley Wilder, "Visualizing Radiation: The Photographs of Henry Becquerel," in Histories of Scientific Observation, ed. Lorraine Daston and Elizabeth Lunbeck (Chicago: Univ. Chicago Press, 2011), pp. 349-368; and on scientific images more generally see Martina Hessler, ed., Konstruierte Sichtbarkeiten: Wissenschafts- und Technikbilder seit der Frühen Neuzeit (Munich: Fink, 2006).

${ }^{13}$ For another account of the constitution of theory and ideology about human life through film technology see Bernard D. Geoghegan, "The Family as Machine: Film, Infrastructure, and Cybernetic Kinship in Suburban America," Grey Room, 2017, 66:70-101. Christina Wessely, "Watery Milieus: Marine Biology, Aquariums, and the Limits of Ecological Knowledge circa 1900," ibid., 2019, 75:36-59, likewise shows how new notions of environment were produced through the material of the aquarium. On the constitution of knowledge by materials of data recording see Christoph Hoffmann, ed., Daten sichern: Schreiben und Zeichnen als Verfahren der Aufzeichnung (Zurich: Diaphanes, 2008).

14 The material and technological "hardware" of film production has still received scant attention. See Jesse Olszynko-Gryn, "Film Lessons: Early Cinema for Historians of Science," British Joumal for the History of Science, 2016, 49:279-286. On photographs and films see Elizabeth Edwards and Janice Hart, eds., Photographs Objects Histories: On the Materiality of Images (London: Routledge, 2004); and Kelley Wilder and Gregg Mitman, eds., Documenting the World: Film, Photography, and the Scientific Record (Chicago: Univ. Chicago Press, 2016). For a sociomaterial approach see Christine von Oertzen, "Keeping Prussia's House in Order: Census Cards, Housewifery, and the State's Data Compilation," in Working with Paper, ed. Bittel et al. (cit. n. 11), pp. 108-123.

${ }^{15}$ On visual technology in the history of infant psychiatry see Felix E. Rietmann, "Seeing the Infant: Audiovisual Technologies and the Mind Sciences of the Child" (Ph.D. diss., Princeton Univ., 2018). On the medialization of human sciences see Ramón Reichert, Im Kino der Humanwissenschaften: Studien zur Medialisierung wissenschaftlichen Wissens (Bielefeld: Transcript, 2007). On the constant interplay of research, display, and education shown through material studies of models see Soraya de Chadarevian and Nick Hopwood, eds., Models: The Third Dimension of Science (Stanford, Calif.: Stanford Univ. Press, 2004); and through the study of images see Hopwood, Haeckel's Embryos: Images, Evolution, and Fraud (Chicago: Univ. Chicago Press, 2015).
} 
to be thought of as human nature. But what brought Baby Teddy and the photographic dome together in the first place?

\section{NORMAL CHILDREN: STATE OF SCIENCE}

As psychological laboratories took hold, children became pliable proxies for various ideas adults had about man in science, society, and the state. In the United States at the end of the nineteenth century, there existed a strong social interest in the child's welfare. In the beginning of the twentieth century, children became "agents of change" in a newly proclaimed "century of the child." The Progressives' views about social reform based on scientific results and methods shifted the focus in the 1920s from the social welfare of the child to a science of the child. The focus changed from the improvement of prevailing living conditions to the potential that normal children and their normal development could offer for a better future, for the nation and for mankind. ${ }^{16}$ Psychology, still a young science, offered the means for work on both the normal and the child by applying general scientific values of exact measurement, prediction, and control to children and their development. For psychologists, in turn, the normal child was a useful scientific subject and a valued object through which their field could develop recognized professional expertise. ${ }^{17}$

Philanthropic foundations spent money on enterprises that created socially useful knowledge of children's health, development, and education, including educational psychology, child psychology, and pediatrics. The activities of the Laura Spelman Rockefeller Memorial (LSRM) were from 1922 front and center in the formation of a new interdisciplinary field called child development research. ${ }^{18}$ Under the headings of child development research, child guidance, and parent education, the goals defined by the LSRM were twofold. First, the organization invested in research to discover more about the nature and needs of children's development and growth. Second, it supported the organization and distribution of scientifically gained knowledge for practical application. ${ }^{19}$ Child development researchers were under pressure to prove that their field produced scientific, yet socially useful, knowledge of children.

Child development researchers were not the only ones in the 1920s with a scientific interest in the child. Experimental psychologists and life scientists engaged children for basic research as one kind of experimental object among a number of others, including rats, monkeys, adult

\footnotetext{
${ }^{16}$ On changing social economies of childhood see Viviana Zelizer, Pricing the Priceless Child: The Changing Social Value of Children (Princeton, N.J.: Princeton Univ. Press, 1994). For "agents of change" and an account of the history of childhood see Karen Vallgarda, Kristine Alexander, and Stephanie Olsen, "Emotions and the Global Politics of Childhood," in Childhood, Youth, and Emotions in Modern History: National, Colonial, and Global Perspectives, ed. Olsen (Basingstoke: Palgrave Macmillan, 2015), pp. 12-34. On developmental perspectives on childhood see Michael-Sebastian Honig, Entwurf einer Theorie der Kindheit (Frankfurt am Main: Suhrkamp, 1999). The phrase "century of the child" was coined by Ellen Key, The Century of the Child (New York: Putnam's, 1909).

${ }^{17}$ On Progressive ideas, human engineering, and psychology, especially at Yale, see Rebecca M. Lemov, World as Laboratory: Experiments with Mice, Mazes, and Men (New York: Hill \& Wang, 2005). On Progressive reforms and child development research see Smuts, Science in the Service of Children (cit. n. 3). On children and psychology see Ellen Herman, "Psychologism and the Child," in The Cambridge History of Science, Vol. 7: The Modern Social Sciences, ed. Theodore M. Porter and Dorothy Ross (Cambridge: Cambridge Univ. Press, 2003), pp. 649-662. On the young field of psychology in practice and science see Kurt Danziger, "Social Context and Investigative Practice in Early Twentieth-Century Psychology," in Psychology in TwentiethCentury Thought and Society, ed. Mitchell G. Ash and William R. Woodward (Cambridge: Cambridge Univ. Press, 1987), pp. 13-33; and Ash, "The Uses and Usefulness of Psychology," Annals of the American Academy of Political and Social Science, 2005, 600:99-114.

${ }^{18}$ Memorandum: Lawrence K. Frank to R. S. Woodworth, National Research Council, Child Study Clearing House and Laboratory in Washington, 20 Dec. 1924, LSRM, Series 3.5, Box 30, Folder 320.

${ }^{19}$ Memorandum: Executive Committee and Director to the Board of Trustees, LSRM, for the year October 1, 1923 to September 30, 1924, LSRM, Series 2, Box 2, Folder 15.
} 
white men, and single cells. ${ }^{20}$ The child served multiple epistemological functions, depending on the interests of the researcher. A prominent assumption was that an infant was naive and unconscious of experimental situations - and therefore a dependable object of study that would reveal original human nature. Children and their development provided evidence for theories of recapitulation and evolution. For theories of the child, in turn, some evolutionary views implied that an infant couldn't own a mind comparable to that of an adult because minds only emerged later in life. An infant's mind was also thought to be by nature like a blank slate, without inscription, and therefore able to show the impact of nurture and education. For behaviorists, babies were a rare experimental black box for the conditioning of behavior. Learning theorists, who drew on the child's developmental characteristics, found proof of the precedence of external factors in development-contrary to the standpoints of embryologists, who insisted on inborn instincts and innate factors for maturing behavior. ${ }^{21}$ Thus scientists derived different kinds of data from children, linked to different theoretical and social conceptions.

Scientists in the new field of child development derived data from the application of "diverse scientific techniques to the individual, growing child in order to portray the development of that single organism" - at least in the idealized view of their organizational leaders. ${ }^{22}$ Their challenge was creating data not only from the individual child subject but also to map mental development, then transforming such data into tangible results for the requirements of child rearing, education, and welfare. Unsurprisingly, the first Handbook of Child Psychology, from 1931 , an outcome of the intense child development research in the 1920s, devoted the introductory chapter to methods of studying development and interpreting the data obtained. Research in children brought several complications. One constraint was the "inaccessibility of the child" through most of the conventional methods of experimental psychology, with the consequence that the main research approach was bound to observed behavior. Another difficulty was finding ways to investigate the "whole child," as was promoted by the LSRM, which differed from methods of calculating statistical averages of age groups or examining single biological functions as discrete units. Taking account of the complexity of a "developing organism," leading child psychologists considered norms "the basic methodological structure upon which an experimental psychology of the child must be constructed." At the same time, this "normative approach" brought "tremendous possibilities" for practical application. ${ }^{23}$

Studies of children before the 1920s concentrated more on deviations than on the normal or on averages. Some reformers and researchers, however, already argued for the significance of the

\footnotetext{
${ }^{20}$ The early behaviorist John B. Watson was among the first psychologists who used the child experimentally. He said in 1919 that "all psychology is 'genetic' in the sense that we have to go back to the child and contrast it with animals in order to determine what native systems of integrations belong peculiarly to man": John B. Watson, Psychology from the Standpoint of a Behaviorist (Philadelphia: Lippincott, 1919), p. 18. The developmental psychologist Myrtle McGraw later found that "the infant and young child are now recognized as useful laboratory animals": Myrtle McGraw, Growth: A Study of Johnny and Jimmy (New York: Appleton, 1935), p. 3.

${ }^{21}$ On naive subjects see Jill Morawski, "Scientific Selves: Discerning the Subject and the Experimenter in Experimental Psychology in the United States, 1900-1935," in Psychology's Territories: Historical and Contemporary Perspectives from Different Disciplines, ed. Mitchell G. Ash and Thomas Sturm (Mahwah, N.J.: Erlbaum, 2007), pp. 129-148, esp. pp. 136-137. Examples of different understandings and utilizations of the child and the child's mind can be found in Smuts, Science in the Service of Children (cit. n. 3); and Hamilton Cravens, "Behaviorism Revisited: Developmental Science, the Maturation Theory, and the Biological Basis of the Human Mind, 1920s-1950s," in The Expansion of American Biology, ed. Keith R. Benson, Jane Maienschein, and Ronald Rainger (New Brunswick, N.J.: Rutgers Univ. Press, 1991), pp. 133-163.

${ }^{22}$ Lawrence K. Frank, "Child Research," 8 July 1932, in American Education Survey, Vol. 2B, Rockefeller Archive Center, General Education Board Records, FA058 (hereafter GEB), Series 7, Box 1.

${ }^{23}$ John E. Anderson, "The Methods of Child Psychology," in A Handbook of Child Psychology, ed. Carl Murchison (Worcester, Mass.: Clark Univ. Press, 1931), pp. 1-27, on pp. 6, 7-8. Regarding the focus on the whole child see Frank, "Child Research," pp. 8-10.
} 
normal child and tried to transfer assessments of the normal from medicine into the field of mental health. Among them was Gesell, who for "democratic" reasons called "the great medium mass of children" the most important group - the group that became the focus of the upcoming child development research. ${ }^{24}$ After the Great War, notions of normality took hold in science and began to enter everyday life. The focus on the normal in children's development preceded the shift from deviance to the normal that the historian Sarah Igo has identified in social science surveys. While a "return to normalcy" was the nostalgic slogan of Warren Harding's successful presidential campaign of 1920, the U.S. Children's Bureau and other national child health organizations campaigned for standardized height and weight norms to improve measures of the normal and distributed normal growth charts to be used in preventive health care on a large scale. ${ }^{25}$ In the 1923 funding policy of the LSRM, normalcy became the cornerstone. Two main imperatives guided the organization's financial support for research and education in child development. First, the LSRM decided that the work it funded should be preventive rather than remedial. The well-being and developmental outcomes of normal healthy children could be enhanced with preventive care; in contrast, sick children and those with special needs required costly interventions. Second, the work should have the greatest possible influence and reach the majority of the population. ${ }^{26}$ Both guidelines had long-term social and scientific consequences, and, significantly, both implied a focus on normal children.

At the Yale Psycho-Clinic, Baby Teddy was chosen as a subject because he matched common ideas of what the normal was at the time. White, healthy, and with parents of middling socioeconomic status, Teddy was in 1927 the first of 107 normal babies from New Haven, Connecticut, who exemplified a combination of several normalities. These child proxies of normal development, though, left gaps in Gesell's attempts to produce unaveraged norms. The initial selection of a normal growth case like Baby Teddy confirmed - in a kind of circular reasoning his universal normality, since the research babies themselves were their own index of normal development. The white middle-class child from New Haven became a universal child to whom children all over the world would be compared. The use of visual tools probably reinforced these politics of selection, while at the same time they responded to social, institutional, and scientific conditions. The photographic dome met the twin expectations of being scientific and distributing knowledge for social application and also reflected Gesell's ideas of what psychology, the normal child, and development were. Certain theoretical assumptions about development seemed to correspond especially well with film technology and found their material expression in the photographic dome.

\section{FOCUS ON THE NORMAL INFANT: DEVELOPMENT}

\section{AT THE YALE PSYCHO-CLINIC}

With the start of the new research program in 1926, the Yale Psycho-Clinic, later renamed the Yale Clinic of Child Development, became one of six flagship institutions of child development

\footnotetext{
${ }^{24}$ Gesell and Chandler Gesell, Normal Child and Primary Education (cit. n. 6), p. vii. See also Cravens, Before Head Start (cit. n. 3); and Smuts, Science in the Service of Children (cit. n. 3). The democratic peer group was white; black children were covered by specialized programs.

${ }^{25}$ Igo, Averaged American (cit. n. 2). On the normal dispersing from science into common use see Cryle and Stephens, Normality (cit. n. 2). See also Katherine Sibley, A Companion to Warren G. Harding, Calvin Coolidge, and Herbert Hoover (Chichester: Wiley, 2014); and Jeffrey P. Brosco, "Weight Charts and Well Child Care: When the Pediatrician Became the Expert in Child Health," in Formative Years: Children's Health in the United States, 1880-2000, ed. Alexandra M. Stern and Howard Markel (Ann Arbor: Univ. Michigan Press, 2004), pp. 91-120.

${ }^{26}$ Memorandum: Executive Committee and Director to the Board of Trustees, LSRM, for the year October 1, 1923 to September 30, 1924, LSRM, Series 2, Box 2, Folder 15.
} 
research and parent education. These major child study centers were promoted by the Laura Spelman Rockefeller Memorial to spread scientific child welfare across the nation. ${ }^{27}$ Gesell, who had received his Ph.D. in psychology in 1906 under the so-called father of child study, G. Stanley Hall, founded the clinic in 1911 while still attending Yale Medical School. Throughout the first years, he engaged with problem children, clinical cases, and school psychology. It wasn't until 1919, by which time Gesell was Professor of Child Hygiene at Yale, that he began investigations into the mental development of normal children. In the three decades that followed, he created detailed norms of developmental stages, making them accessible in developmental schedules and diagnostic tests for use by physicians, psychologists, and teachers. Gesell's books, films, and other publications molded an understanding of the child's developmental nature within a diverse range of academic disciplines and child-related professions. His reach also extended into private homes, where his ideas about child-centered education and parenting based on developmental knowledge made him America's most popular child expert before Benjamin Spock. When he retired from Yale in 1948, Gesell was internationally renowned for his contributions to developmental psychology, pediatrics, and child guidance. Almost thirty years after his death, a former collaborator reminisced: "In countless homes the name of Arnold Gesell was better known than that of the President of the United States. And to a great number of occupants of these homes, Arnold Gesell was a far more important man than the occupant of the White House." 28

The Mental Growth of the Pre-School Child, published the year before the photographic research program started, marked the first systematic attempt to delineate the normal psychology of infancy, an age previously neglected in child research. In this successful book, Gesell outlined his first developmental milestones and used two hundred photographs to depict "ordinary and normal behavior" of "representative" infants and preschool children at ten different age levels ranging from one month to six years. ${ }^{29}$ Most of the pictures were snapshots Gesell had taken himself with a small photo camera and had been intended for clinical use rather than for his research. The rest came from a newsreel that Pathé Review had produced about novel scientific work with children. Photographs and film stills were added to the publication as a "normative reference" and an "aid to classification" for researchers and child workers, who could match a living case to the pictured children by way of a differential diagnostic method. Though the pictorial outline clustered typical behavior situations at a single age level (see Figure 2) and presented the clusters in chronological order, the analytic interpretation of the developmental data applied a comparative view to different children at different age levels. This was also the principle Gesell used to demonstrate developmental change live on stage in a lecture hall, where he compared two infants of different ages and regretted "that no individual can at any stage be brought into immediate comparison with what he was or will be." ${ }^{30}$ The supplementary pictures in Mental Growth of the Pre-School Child didn't change how he visualized development. Seeing development

\footnotetext{
${ }^{27}$ Frank, "Child Research" (cit. n. 22).

${ }^{28}$ Citation of an obituary in the New Haven Register, 30 May 1961, in Louise Bates Ames, Arnold Gesell: Themes of His Work (New York: Human Sciences, 1989), p. 234. For more on his professional biography see Gesell, "Autobiography" (cit. n. 5); Walter M. Miles, Amold Lucius Gesell: A Biographical Memoir (Washington, D.C.: National Academy of Science, 1964); Thomas Fagan, "Gesell: The First School Psychologist, Pt. 1: The Road to Connecticut," School Psychology Review, 1987, 16:103-107; and Weizmann and Harris, “Arnold Gesell” (cit. n. 5). For Gesell's impact on education see Grant, Raising Baby by the Book (cit. n. 4); and Hulbert, Raising America (cit. n. 4), pp. 154-187.

${ }^{29}$ See Weizmann and Harris, "Arnold Gesell"; and Gesell, Mental Growth of the Pre-School Child (cit. n. 6), p. 3.

${ }^{30}$ Gesell, Mental Growth of the Pre-School Child, pp. 160, 281. Gesell later credited the Pathé production as his inspiration for a cinematographic investigation of child development: Gesell, “Autobiography" (cit. n. 5), pp. 131-132. The film itself, also titled The Mental Growth of the Pre-School Child (New York: Pathé Review, 1923), is lost.
} 


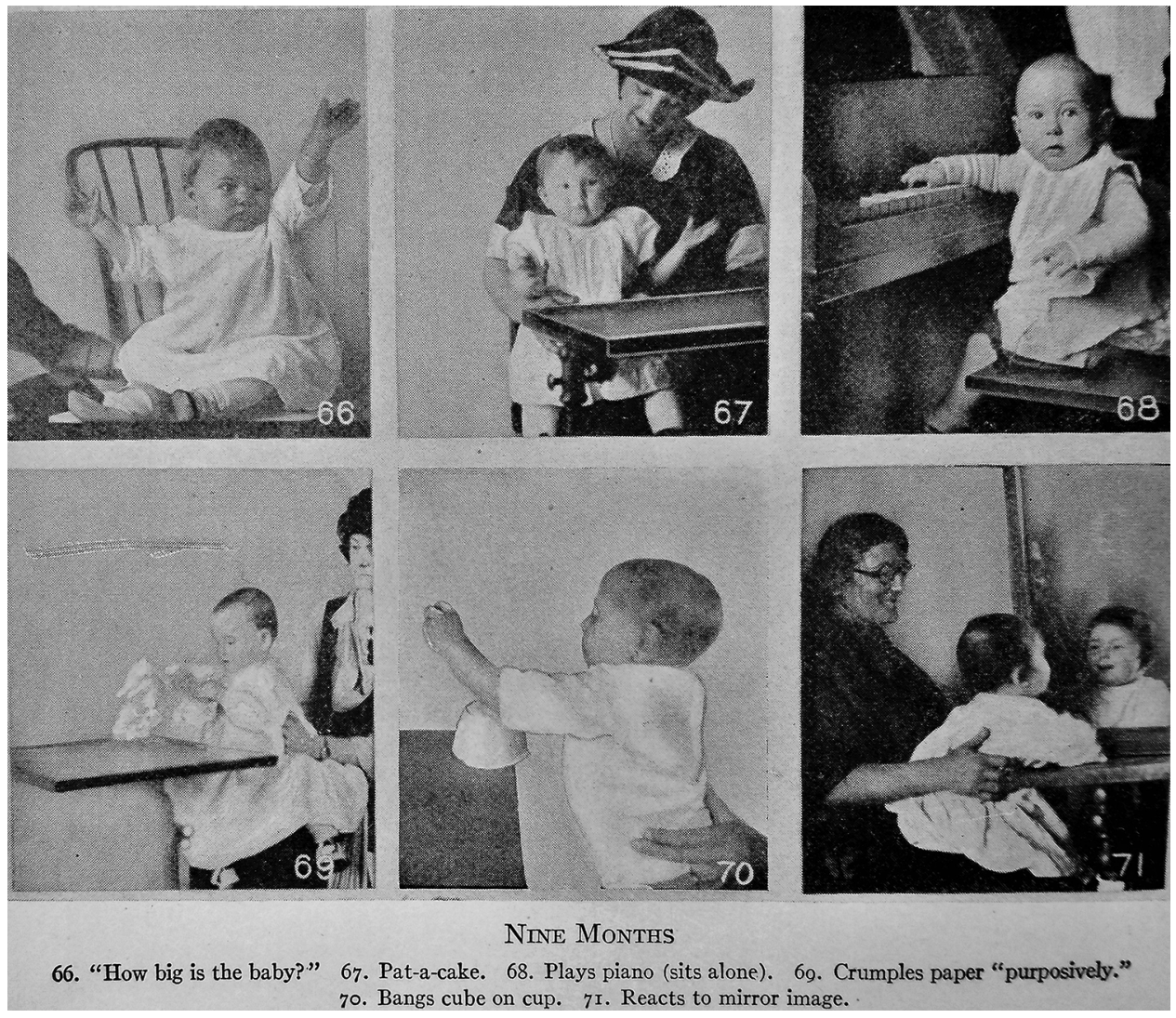

Figure 2. Gesell's first published photographs from 1925 showed clusters of characteristic behavior situations, here at nine months. Image: Arnold Gesell, The Mental Growth of the Pre-School Child (New York: Macmillan, 1925), p. 171.

was still a matter of cross-sectional pairing, whether by arranging living babies or photographs of them.

The pictures also functioned further to legitimate methods of studying the development of the infant mind. Gesell drew on developmental theories and procedures of embryology, a more established scientific field with a strong visual tradition, and transferred morphogenetic concepts based on pictorial series in embryology to developmental psychology. Establishing a logical correspondence between development and pictorial series further tied the two fields together and made film a methodological option. In his publication from 1925, Gesell explicated analogies between the embryologist's "detailed sectional views of growing organisms" and a "continuing series of sections corresponding to the stages and the moments of development" as visualized in a series of pictures. Development was "at least a series of moments" and the cinema film was "a series of static pictures," he reasoned, creating an "analogy" between development and film that would not "altogether break down in the domain of mental development." Inherent in both pictorial series and child development was the factor of time. For the study of early infancy, Gesell suggested, "we must make certain readjustments in our accustomed time sense," viewing "infant behavior through lenses which will deepen perspective." In infancy, even units of short duration had great developmental significance. The importance of a psychology of infancy was plausible both in the fact that, as in physical growth, "more' development is 
compressed" in the early stages of life and in the reasoning that "it comes first" and must, therefore, be the most consequential period. ${ }^{31}$

Physical growth could be recorded in inches and pounds. The unit for recording mental development was behavior, conceived as "the functional index of developmental maturity." 32 More than a decade of discussions about behavior as an objective category of psychology had opened new perspectives for methodologically accepted psychological investigations of infants and children. ${ }^{33}$ Gesell could now correlate behavior to an "interpretation of 'mind," "which was no longer related to a psychology of consciousness based on introspective methods or metaphysical aims. Drawing on findings from embryology regarding the relation of the nervous system and behavior, though not at all sure what "mind" was at this early stage of life, he moved the "psychology of infancy" into closer relation with neurology, physiology, and biology. Mental growth manifested itself in visible forms of behavior, Gesell later wrote with regard to his photographic and film techniques - meaning that mental development was not invisible but could be captured in pictures and could thus be analyzed and measured, as in the case of any other exact science. ${ }^{34} \mathrm{In}$ declaring developmental psychology to be a psychology of behavior, Gesell created an opportunity to use visual techniques for observation and analysis. At the same time, photography and film established analogies to recognized scientific fields and, accordingly, a firmer scientific standing for the study of mental development in infancy.

The photographic series, which resembled the visual narratives of photo stories in popular magazines, probably contributed to the success of the first developmental milestones for babies published in Mental Growth of the Pre-School Child and helped in 1926 to pave the way for a major child study grant from the Laura Spelman Rockefeller Memorial. The grant application was carefully prepared by the office of Yale's president, the psychologist James Rowland Angell, who drew on former connections with the LSRM's director, Beardsley Ruml. In several letters he stated the importance of Gesell's work, suggesting that the researcher would be "on the track of one of the most useful contributions that has been made in recent years to the study of behavior and to the control of adult personality." The title of the research proposal read "A PLAN for developing at Yale University an organization devoted to THE SCIENTIFIC STUDY OF NORMAL INFANCY and concerned with the problems of child development from the standpoint of parent guidance and of psycho-biological research." The proposal was a program for both research and demonstration in developmental psychology and mental hygiene. The study of early normal infancy had three objectives: to be a scientific endeavor; to enable developmental diagnosis and prediction; and to be economically and sociologically significant. Gesell proposed five main fields of future activities, among them the psychoclinical service he already provided, an extension of his infant behavior research, and the photographic research, which Angell's letters praised as a real contribution "to the scientific significance of moving pictures." ${ }^{35}$ Only this photographic program still had to be developed in detail.

\footnotetext{
31 Gesell, Mental Growth of the Pre-School Child, pp. 24-26, 203, 20, 10. On visual series in embryology see Hopwood, Haeckel's Embryos (cit. n. 15); and Wellmann, Die Form des Werdens (cit. n. 9).

${ }^{32}$ Gesell, Mental Growth of the Pre-School Child, p. 8; and Arnold Gesell, "Monthly Increments of Development in Infancy," Pedagogical Seminary and Joumal of Genetic Psychology, 1925, 32:203-208.

${ }^{33}$ On behavioral approaches in child psychology see Anderson, "Methods of Child Psychology" (cit. n. 23); and Gesell, Mental Growth of the Pre-School Child, pp. 27-36.

${ }^{34}$ Gesell, Mental Growth of the Pre-School Child, pp. 8, 188; and Arnold Gesell, An Atlas of Infant Behavior: A Systematic Delineation of the Forms of Early Growth of Human Behavior Patterns, 2 vols. (New Haven, Conn.: Yale Univ. Press, 1934), Vol. 1: Normative Series, p. 15.

35 James Rowland Angell to Beardsley Ruml, 20 Mar. 1925, LSRM, Series 3.5, Box 47, Folder 492; Proposal for a Developmental Research Clinic, ibid.; and Angell to Ruml, 20 Apr. 1926, ibid.
} 
The alliance of science and motion pictures had a history of more than half a century by the time the film technology in Gesell's photographic program encountered normal babies, development, and psychology. The precedents on which Gesell drew when aligning film and mental development were motion studies like Eadweard Muybridge's chronophotographic series of galloping horses and crawling children and the industrial psychologists Frank and Lillian Gilbreth's use of cinematography to enhance workflows. Both of these were notable for the use of different temporal dimensions in recording, analyzing, and demonstrating successive phases of a behavior event. ${ }^{36}$ As instruments of mechanical observation and recording, cameras were promising to make a contribution to the objective practices to which psychologists aspired. ${ }^{37}$ John B. Watson had previously used the film camera in this manner for documenting infant behavior. But Watson's method of extending observational eyes and memory was not what Gesell aimed for. Gesell proposed "to go beyond the ordinary auxiliary utilization of the camera and make photographic technique and pictorial records a major research objective." The photographic research program would produce new methodological procedures as well as "substantive data which to a high degree will be disseminative." ${ }^{38}$ Film technology and data brought research, publication, and education into close interrelation.

The proposal praised film technology for its double function of providing methods and data for both research and communication. "Photographic techniques" and "material" could attain a "much wider range of both scientific and educational influences" and had "educational value" for students, laboratories, professionals, and parents. The plan for this psychology of infancy relied on an interplay of production and representation of knowledge, the "epistemological unit" that film formed. ${ }^{39}$ Film introduced aspects of dissemination into the laboratory construction and linked the elusive subject of an infant mind with the serial chronology of development and behavior as a category of psychology. During the first two years of the program, called the "exploratory period," there was a slight but important shift in the position of the photographic research within the project. Begun as a self-contained element within the program, the photographic and film investigation was by 1928 an integral aspect of the developmental and clinical research, indicating the intertwining of photographic material, techniques, and data with research objectives and results. ${ }^{40}$

Once Gesell had secured \$125,000 in Rockefeller funding for the following five years, he moved the Psycho-Clinic to larger quarters and engaged five new staff members. Each had a

\footnotetext{
${ }^{36}$ Gesell, Mental Growth of the Pre-School Child (cit. n. 6), p. 160; and Arnold Gesell, "Cinemanalysis: A Method of Behavior Study," Pedagog. Sem. J. Genet. Psychol., 1935, 47:3-16. See also Edgar S. Garcia, "Muybridge y Gesell: Pioneros de los métodos de investigación visual en psicología," Revista Costarricense de Psicología, 2012, 31:191-210; and Scott Curtis, "Images of Efficiency: The Films of Frank B. Gilbreth," in Films That Work: Industrial Film and the Productivity of Media, ed. Vinzenz Hediger and Patrick Vonderau (Amsterdam: Amsterdam Univ. Press, 2009), pp. 85-99. On temporal dimensions of scientific film see Hannah Landecker, "Microcinematography and the History of Science and Film," Isis, 2006, 97:121-132.

${ }^{37}$ Although photographic and film technologies have been perceived as being objective, they were not per se congruent with the ideal of mechanical objectivity described in Lorraine Daston and Peter Galison, Objektivität (Frankfurt am Main: Suhrkamp, 2007).

${ }^{38}$ For Gesell's ambitions for photography see Supplementary Statement for the Proposal, LSRM, Series 3.5, Box 47, Folder 492. For Watson's use of the still camera see John B. Watson, Studies upon the Behavior of the Human Infant: Experimental Investigation of Babies [film] (Chicago: Stoelting, 1919); and Ben Harris, "The Role of Film in John B. Watson's Developmental Research Program: Intellectual, Disciplinary, and Social Influences," in Contributions to a History of Developmental Psychology: International William T. Preyer Symposium, ed. Georg Eckhardt, Wolfgang G. Bringmann, and Lothar Sprung (Berlin: Mouton, 1985), pp. 359-366.

${ }^{39}$ Supplementary Statement for the Proposal; and Summary of the Work, 1926-27, for Mr. Ruml, LSRM, Series 3.5, Box 47, Folder 493. On the "epistemological unit" see Janina Wellmann, "Science and Cinema," Sci. Context, 2011, 24:311-328, on p. 322 .

${ }_{40}$ Annual Report, July 1, 1927-June 30, 1928, LSRM, Series 3.5, Box 47, Folder 493.
} 
different specialization in psychology, pediatrics, and education and brought a different investigational perspective on the developing child. The photographic dome, which the researchers constructed as the centerpiece of the whole program, had assigned positions and tasks for everyone and everything. This arrangement expanded what had been the experimenter-subject relation of psychology into a multidimensional dynamic system of human and techno-material participants. The construction of the dome, and the configuration of people and technology within and around it, carried a theoretical preunderstanding of film, developmental psychology, and the normal that was also embedded in the photographic data production. The dome's "materialized epistemology," however, went beyond the photos and films that were produced there for science and education. ${ }^{41}$ The work of constructing the dome and establishing the photographic and film techniques was the work of conceptualizing normal mental development. Thinking with the materials of film production constituted theories and ideologies concerning the normal child and configured a developmental psychology that differed from the assumptions Gesell and his team previously held. The photographic dome produced knowledge of normal development even before the photographs and films were used.

\section{THE PHOTOGRAPHIC DOME: TECHNOLOGY OF ARTIFICIAL} CONTROL AND NATURAL BEHAVIOR

Gesell appreciated what he considered to be the homelike atmosphere of the new Psycho-Clinic building, an impressive villa originally constructed as a private residence (see Figure 3). He hoped that it would encourage the confidence of parents and children who entered the clinic. "There are human factors inherent in the nature of the work," he later summarized his experience, calling for special architectural considerations that included an emphasis on health and normality rather than medical and mental disorders. Gesell wished to elicit from the child as well as the parent behaviors that were as natural as possible under the artificial conditions of scientific observation and clinical examination. Naturalness was expected to occur in an environment where the child was not beset by unfamiliar attractions and encountered as little social stimulus as possible. ${ }^{42}$ Indeed, Gesell seemed to see natural infant behavior as a kind of normal zero state, although the normal natural needed to be ensured through artificial technology and solitude.

Gesell and his team spent the first months in their new residence devising special constructions and designs for what they called the Photographic Laboratory. The physical core of this new laboratory was a dome-shaped steel construction, later named the "photographic dome." This dome was simultaneously an observatory, a film studio, and an experimental laboratory. Its scientific goals were observation that went unnoticed and the recording of behavior that was optimized under standardized, controlled, and, therefore, repeatable conditions. The dome's construction started immediately with the arrival of a new staff member, the experimental psychologist Henry M. Halverson. In one of his first staff meetings Halverson already illustrated how children would be placed in a "photographic crib" in a "new revolving 'room.' "Whatever it was called - whether just the "room" or, more magnificently, the "photographic house," the "cupola,"

\footnotetext{
${ }^{41}$ On the "experimenter-subject system" see Jill Morawski, "Epistemological Dizziness in the Psychology Laboratory: Lively Subjects, Anxious Experimenters, and Experimental Relations, 1950-1970," Isis, 2015, 106:567-597, on p. 574. "Materialized epistemology" is taken from Norton M. Wise, "Making Visible," ibid., 2006, 97:75-82; and Hannah Landecker, "Creeping, Drinking, Dying: The Cinematic Portal and the Microscopic World of the Twentieth-Century Cell," Sci. Context, 2011, 24:381-416

${ }^{42}$ Memorandum: Gesell for Angell: Architectural and Organizational Provisions for the Study of Infancy and Child Development, 19 Nov. 1928, LSRM, Series 3.5, Box 47, Folder 493. On the child's natural environment and the artificial conditions for behavior observation see Gesell, Mental Growth of the Pre-School Child (cit. n. 6); and Gesell, Infancy and Human Growth.
} 


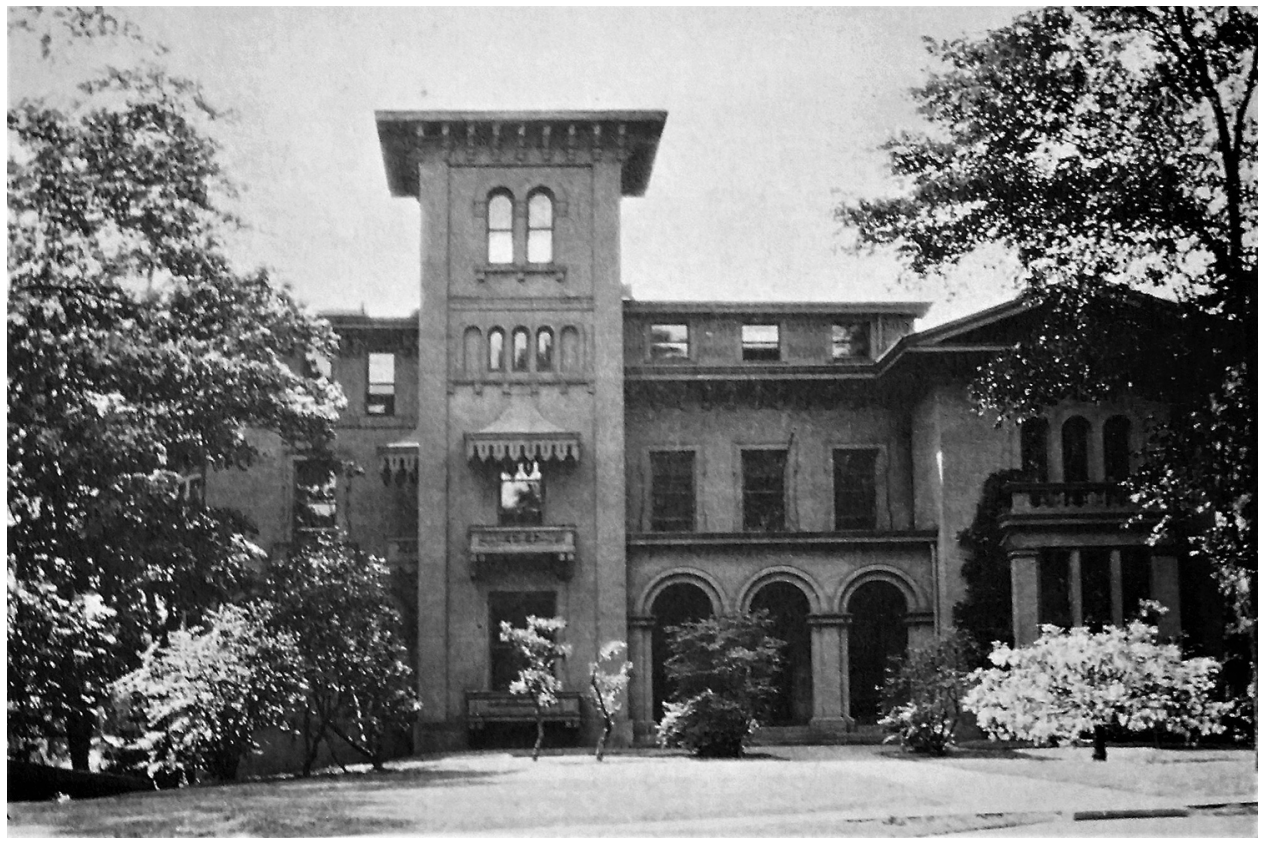

Figure 3. Residence of the Yale Psycho-Clinic from 1926 to 1930. Image: Arnold Gesell, An Atlas of Infant Behavior, 2 vols. (New Haven, Conn.: Yale Univ. Press, 1934), Vol. 2: Naturalistic Series, p. 545; reproduced with kind permission of the Yale Child Study Center.

the "photographic observatory," or, eventually, the "photographic dome" - the hemispherical high-tech construction, "the reverse of its astronomic prototype," was installed in December 1926 and the first trial examinations were scheduled to test its various features (see Figure 4). ${ }^{43}$

Generating natural behavior through artificial control was a core idea behind the laboratory dome. In order to detect developmental change unaffected by the test conditions, the dome needed artificial illumination. Halverson experimented with several designs to find lighting strong enough to permit photography with only a short exposure time yet dim enough that it would not disturb the child. In Gesell's words, the aim was to photograph the child "in action, but under 'natural' conditions." The researchers rejected both dazzling arc lights and weak incandescent lights, then solved a noise problem that arose from the auxiliary converting the current for the state-of-the-art mercury vapor lamps from Cooper-Hewitt. Halverson fixed the lamps around the rotunda in two open cabinets covered with tissue paper screens to soften the bright light into a suffused shine. The curved surface of the dome wall reflected the light in such a way that it was augmented in the central "focal area," where the child was placed in a specially constructed crib. By January 1928 Halverson had succeeded. The child could be illuminated with a soft, noiseless, and cool light that served the three aims of facilitating naturalness of behavior, enabling photographic recording, and maintaining uniform conditions of experimental control. ${ }^{44}$

\footnotetext{
${ }^{43}$ Notes of Staff Meeting, 22 Oct. 1926, 3 Dec. 1926, 10 Dec. 1926, Gesell Papers, Box 129; and Gesell, Infancy and Human Growth, p. 60.

${ }^{44}$ Gesell, Infancy and Human Growth, pp. 58, 58-59; and Correspondence with Cooper-Hewitt Electric Co., Jan.-June 1927, Gesell Papers, Box 67. On seeing the real through artificial laboratory constructions see Lemov, World as Laboratory (cit. n. 17);
} 
How to conduct observations independent of the personal skills and impressions of the observer was a question widely discussed, in psychology as in other sciences. How to observe without being noticed was the obverse of this question, a challenge attendant on observing humans. In Gesell's work, as elsewhere, both problems were addressed by training observers and employing technology. ${ }^{45} \mathrm{~A}$ common technique at the time was observation through a peephole or a small glass window, which Gesell used before he installed the dome. The dome enhanced these "techniques of secrecy" with an invention named the "one-way-vision screen" that was wrapped around the steel construction. ${ }^{46}$ The screen, which was a simple do-it-yourself device, consisted of 16-mm mesh wire painted white on the inside to reflect the light. When the surrounding room was kept dark, the observers could see the illuminated child inside the dome without the child seeing them.

Around the dome, but also in other examination rooms and in the guidance nursery, the novel screen provided enough space for a whole group of concealed observers. Gesell seated students, professionals, and parents behind the screen for live demonstrations of his examination method and the child's behavior. Indeed, he and his team had discussed the educational use of such a screen even before they discussed the design of the dome. In the dome's laboratory function, the one-way-vision screen was "the cloak of invisibility of the fairy tale" and served "medical and scientific standards of control" through "segregated observation." ${ }^{\text {"7 }}$ Isolating staff members, the mother, and the surrounding material environment from the child's view was meant to remove uncontrollable interference. Through artificial solitude, the dome staged a more-than-real-life naturalness of the child.

Devised as observatory, film studio, and laboratory, the photographic dome also needed special interior equipment that served simultaneously as experimental tool, set equipment, and scenic design. Drawing on sketches by Gesell, Halverson designed a special clinical crib that was placed at the "universal focal point" in the center of the dome. The crib's task was to make manifest every single step of the child's examination. Its adaptable parts helped to facilitate standardized examinations, to switch between different test situations without interruption, and to create "a situation favorable for children" of different age levels. The crib adapted smoothly to the rapidly changing developmental states and inclinations of the children - for example, by looking more like a playpen than a bed in some situations, "to overcome their objection to going to bed in the daytime." In addition to this situational and long-term continuity, the crib allowed for unhindered observation and photography. The incorporated tabletop had markings to ensure

and Kurt Danziger, Constructing the Subject: Historical Origins of Psychological Research (Cambridge: Cambridge Univ. Press, 1990).

${ }^{45}$ Observation and objectivity are an enduring concern in the history of science, although mostly with regard to the observer. See, e.g., Daston and Lunbeck, eds., Histories of Scientific Observation (cit. n. 12). On observation in early child study see Christine von Oertzen, "Science in the Cradle: Milicent Shinn and Her Home-Based Network of Baby Observers, 1890-1910," Centaurus, 2013, 55:175-195. For a history of psychology that stresses the reflexivity of human sciences in observer/experimentersubject relations see Morawski, "Epistemological Dizziness in the Psychology Laboratory" (cit. n. 41).

${ }^{46}$ For secretive observation techniques see Letters of English Bagby, 1929, Gesell Papers, Box 19; and Carl Newton Rexroad, General Psychology for College Students (New York: Macmillan, 1929), p. 358. On "techniques of secrecy" and separation to control both observer and subject see Morawski, "Scientific Selves" (cit. n. 21), p. 137.

${ }^{47}$ For early discussion of the educational use of a screen see Notes of Staff Meeting, 1 Oct. 1926, Gesell Papers, Box 129. On its use as "the cloak of invisibility" see Gesell, Infancy and Human Growth, p. 30. For more on the one-way-vision screen see Manual for Screen Production and Memoranda, Gesell Papers, Box 103. For the planning of live demonstrations see Notes of Staff Meeting, 5 Nov. 1926, 21 Jan. 1927, Gesell Papers, Box 129. Gesell's and others' later utilization of one-way-vision facilities has been associated with surveillance practices and Foucault's panopticon discussion. See, e.g., Lakoff, "Freezing Time" (cit. n. 9); and Deborah Weinstein, The Pathological Family: Postwar America and the Rise of Family Therapy (Ithaca, N.Y.: Cornell Univ. Press, 2013), pp. 150-155. 

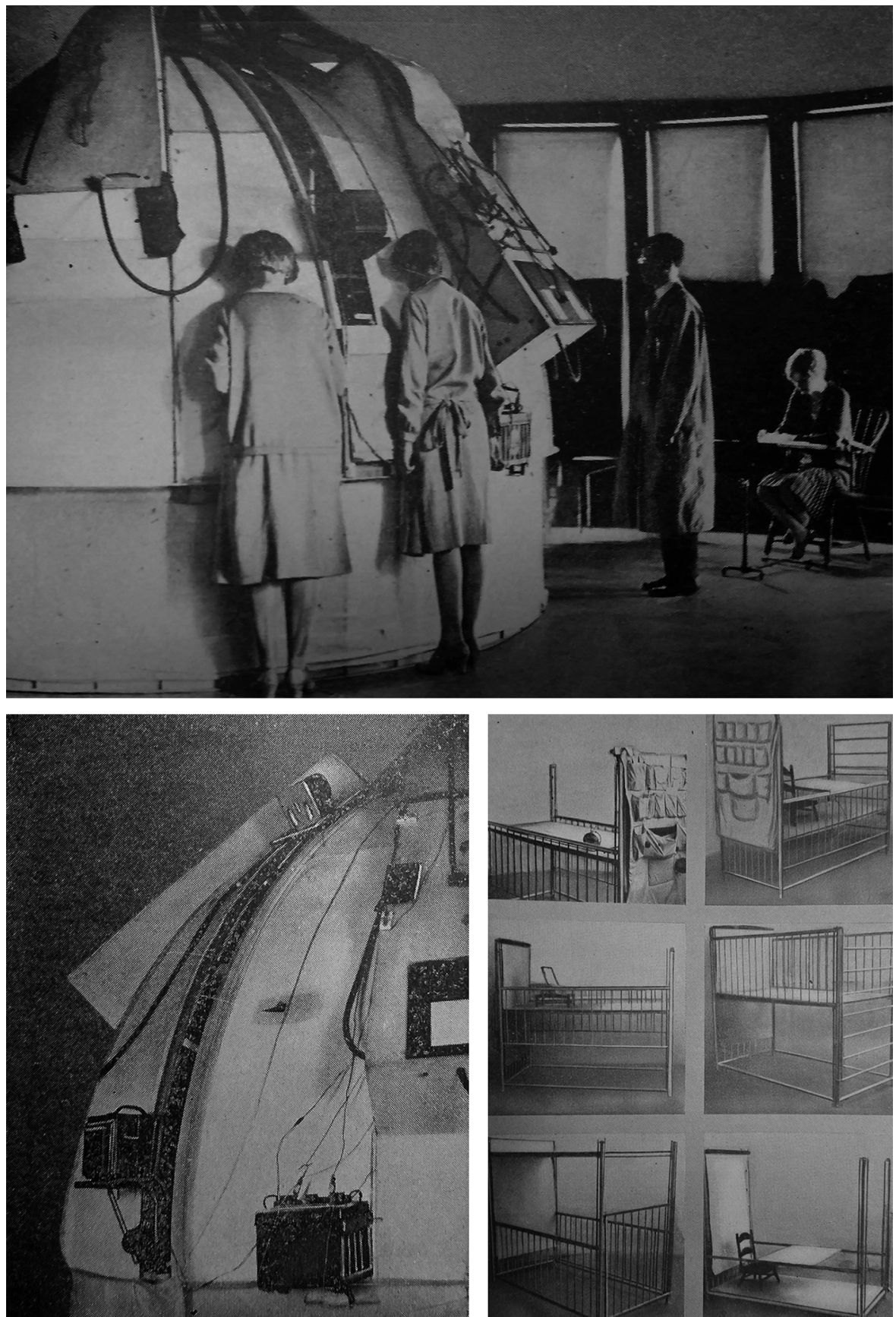

Figure 4. Top: Observers and recorders in the darkened room; photographic dome with camera track, illumination cabinet, wiring, and researchers. Bottom, left: Camera track with mounted still and motion cameras; wiring for the electrical control of the cameras. Bottom, right: Clinical crib with adjustable parts. Images: Arnold Gesell, Infancy and Human Growth (New York: Macmillan, 1928), pp. 67, 65, 51. 
the correct and identical placement of objects during every examination, which both facilitated continuity and kept materials and human participants in the cameras' focus. ${ }^{48}$

The dome held two cameras - "instantaneous and cinema cameras" - that were boxed into wood that silenced their operation so as not to distract the child being studied. The cameras could slide up and down on two quadrants of the steel frame, and the upper part of the dome could rotate, allowing shots of the child in the focal center from repeatable positions at any angle. The dome's spherical form kept the cameras' focus steady. One camera operator-initially Halverson and later a trained janitor-could operate the two cameras simultaneously, resulting in two pictures from different angles, each of which was "a supplement and analytical critique of its companion." Even overhead pictures from the zenith point were possible, providing a view of the "postural stance" an ordinary human observer never had. ${ }^{49}$ The cameras, together with the architecture of the dome, provided enhanced observation and the continuity of uniform conditions.

When thinking ahead to the "scientific study of the material, the optical records themselves," and their proposed "educational utilization," the team around Gesell anticipated that, "regarding still picture vs. motion picture," they would rely more and more on the cinema cameras. The main advantage, Gesell observed, was that "actually a motion picture is a series of still pictures." While film caught the "continued motion" needed, the "dynamic strip" could also be stopped for the analysis of single moments of motion or cut into still pictures serviceable for visual education without requiring film projectors. Film shared these valuable properties or "identities" with single photographs. In addition, the "cinema strip" kept the picture series together in a single continuum, thus promising a compact solution for handling the Psycho-Clinic's multiplying visual material. Film, Gesell added, duplicated itself "at a smaller price than that of a book" and was "a new form of publication." ${ }^{50}$ Privileging motion over still pictures was at this stage of their work due to neither the analytical potential nor the visual pervasiveness of moving images. Rather, the film strip's practical form was considered preferable for both scientific use and dissemination.

One year after the Yale Psycho-Clinic moved into its new building and the team started the design and construction work, Gesell noted in one of the speeches he habitually gave at staff meetings that combining naturalness with improved observation was one of their most tangible achievements. "By means of the dome we are enabled to preserve the naturalistic aspect of the infant which we have insisted upon, and with gain rather than loss in the observation," he concluded. With ingenuity, Rockefeller's money, and the craftsmanship of Halverson, Gesell had materialized his vision of experimental scientific observation that respected the babies' human nature and illuminated their developmental changes. The appearance of the steel dome, equipped with electronics and sophisticated machinery, stood in stark contrast to the appearance of the lovely rosy child. Nonetheless, Gesell was not afraid that the monstrous high-tech construction would intimidate the infant or unduly influence his behavior. To control any disturbing factors, he placed the entrance to the observatory near an independent doorway, so that the infant's first impression would be quite ordinary: The infant "is released rather than hampered by the physical arrangements. ... So far as he is concerned he is basking in the light of a bright, airy, though windowless, room." ${ }^{\text {1 }}$

Publications have mostly pictured the dome with people in place: the examiner and child are inside, surrounded by staff members, parents, and other observers outside, indicating a

\footnotetext{
${ }^{48}$ On the crib's adaptations see Notes of Staff Meeting, 10 Dec. 1926, Gesell Papers, Box 129. Regarding the tabletop see Notes of Staff Meeting, 22 Oct. 1926, ibid.; and Gesell, Infancy and Human Growth, pp. 50-55.

${ }^{49}$ On the cameras as "supplement and analytical critique" of one another see Summary of the Work, 1926-27, for Mr. Ruml, LSRM, Series 3.5, Box 47, Folder 493; and Gesell, Infancy and Human Growth, p. 64. Regarding the "postural stance" see Notes of Staff Meeting, 8 Oct. 1926, Gesell Papers, Box 129.

${ }^{50}$ Notes of Staff Meeting, 5 Nov. 1926, Gesell Papers, Box 129.

${ }^{51}$ Notes of Staff Meeting, 27 Oct. 1927, ibid.; and Gesell, Infancy and Human Growth, p. 61.
} 
sociotechnical interplay. The division-of-labor configuration of research work around the dome combined experimental observations with clinical and natural observations, complemented photographic records with written recordings, and coordinated human and technical observers and recorders. Such was the "stage" on which Teddy and the other children cheerfully played while being scientifically observed. ${ }^{52}$ In order to turn their play into experimentally useful child behavior and transform it into developmental data, Gesell and his team tried to develop examination and recording procedures that matched scientific standards and their idea of the normal while providing for human and photographic needs.

\section{PHOTOGRAPHIC SEQUENCES: TECHNIQUES OF NORMAL DEVELOPMENT}

In the process of designing procedures and techniques to study the developing child, film technology gradually took the lead. Before 1926, Gesell still used an approach that he described as "being of the clinical and natural-history type." "No effort was made to place the subjects under rigidly uniform experimental or laboratory conditions," he had declared. Now Gesell announced to his new team that they wouldn't be content with using photography merely to illustrate the "current behavior and capacity of the child" as formulated in developmental norms. Norms were instrumental for their research to "get the effect of time on the development of the children." Gesell opined that photography and film had the potential to get "something more-fundamental." These "fundamental things," which were related to questions of posture, prehension, and attitudes, and thus were "so psycho-biological," had "their proper sequences." The task Gesell set for his team was a methodological one: to capture the core of development. Whatever their techniques were going to be, they had to ensure "standardization in methods and procedures" to "seriate the photographs." ${ }^{\prime 3}$

Like the design of the dome itself, the design of the examination procedures followed principles of uniformity, continuity, and natural behavior, including considerations about how to control the human factors of mother, child, and researchers. The mother played an important role. She often spent half a day or longer in the Psycho-Clinic while the researchers interviewed her, anthropometrically measured her child, and observed both mother and child at all times. While the child needed to be well rested and well adjusted in order to show vivid reactions to the test objects and stay "happy and responsive" throughout the photographic procedure, the mother had to stay calm and cooperative; it was thus helpful to make her acquainted with the daunting dome technology in advance. Gesell's team tried to incorporate the mothers into the research program and rewarded participating families with special guidance on child rearing, hoping to establish the necessary personal commitment. Mothers invested a good deal of their time. They agreed to bring their newborn child to the clinic every four weeks during the first year of life and then attend regular follow-ups. Unsurprisingly, many children dropped out before they had made it through the first year. Other irregularities that put the continuity of developmental examinations at risk were also common. A serious problem was that infants seemed to have their own will and moods. This endangered the uniformity of the child subjects and the sequence of their examination, as the procedure often had to be adapted to the individual dynamics of an actual situation. ${ }^{54}$

\footnotetext{
52 Gesell, Infancy and Human Growth, p. 59.

${ }^{53}$ Gesell, Mental Growth of the Pre-School Child (cit. n. 6), p. 42; and Notes of Staff Meeting, 8 Oct. 1926, 8 Oct. 1927, 8 Oct. 1926, Gesell Papers, Box 129.

${ }^{54}$ On the importance of keeping mothers engaged and involved see Notes of Staff Meeting, 1 Feb. 1926, 29 Oct. 1926, 19 Nov. 1926, 18 Jan. 1927, Gesell Papers, Box 129; and Proposal for a Developmental Research Clinic, LSRM, Series 3.5, Box 47,
} 
That "play is the infant's work" was a core assumption of the examination materials and procedures. Infants took toys seriously, as did Gesell. The examination materials, including toys made by the Psycho-Clinic's janitor and objects familiar from daily life-red cubes, rings with strings, paper and crayons, cup and spoon - took on "the disguise of playthings" to tease out natural reactions under standardized conditions. ${ }^{55}$ In the early phase of the program, Gesell himself, along with Helen Thompson, the psychologist who was in charge of developing examination procedures and developmental tests, conducted all the clinical examinations to avoid reaction differences. They tried to establish a friendly though not overly cordial relationship with the infant to support the neutral behavior they hoped to observe. Although they found a personal subject-examiner relationship important, they stuck to the ideal of experimental solitude and considered procedures to eliminate their own social influence on the child as far as possible. The examiner, usually the only person inside the dome with the child, was simultaneously also the observer. Since Gesell couldn't employ an additional staff member experienced enough to make reliable observations from outside the dome, he had to break the principle of controlling both the child and the observer by means of the one-way-vision segregation screen. However, both he and Thompson soon saw the advantage of more immediate observations while in close contact with the child. ${ }^{56}$ In addition, the division-of-labor design of the dome would counterbalance their human imperfections with two observing camera eyes.

The motion cameras were Gesell's super observers and recorders. "The camera is, in a sense, mightier than the psychological eye," Gesell argued. The camera made it possible to "catch what eludes," to store "sequences of growth" for "retrospective reference," to "adjust the durational interspaces" between behavior levels and, thereby, to visualize the developmental process of mental growth. A simple but helpful feature of the film technique was that "to some extent time will be self-registered in the case of the cinema strip" for later behavior examinations of the recorded child. ${ }^{57}$ For a methodology of mental development, the camera's chief asset was the observational manipulation of time and space that created continuity.

Gesell and his researchers relied on the motion picture cameras to preserve what they couldn't yet see. "The undiscovered thing is hidden by assumptions that we too readily make," he noted in alerting his team against premature "logical classifications" of behavior sequences and the introduction of a "fictitious uniformity in the data." Once they knew what to look for, they could come back to what was "indefinitely preserved" and "embedded in the motion picture." Yet Gesell and his team found that the mighty eyes also had their limitations, including selective scale and framing, restricted filming duration, and noisiness. Despite all the measures to control external effects and the "performative, role-taking capacities" of the babies, who in general were reckoned uncomplicated subjects unconscious of the experiment, some children nevertheless reacted to human and technological distractions. ${ }^{58}$ They also became aware of the

Folder 492. On the problems imposed by the wills and moods of infants see Gesell and Thompson, Psychology of Early Growth (cit. n. 1); and Gesell and Thompson, Infant Behavior (cit. n. 1).

${ }^{55}$ Gesell and Thompson, Infant Behavior, p. 35.

${ }^{56}$ Regarding observers' behavior within the dome see Annual Report, July 1, 1927-June 30, 1928, LSRM, Series 3.5, Box 47 , Folder 493; and Gesell and Thompson, Infant Behavior, p. 42. On what proved to be the advantages of immediate observation of the child see Notes of Staff Meeting, 22 Oct. 1926, Gesell Papers, Box 129. Helen Thompson, Ph.D., was research assistant for biometry and was trained in statistics and anthropometrics.

${ }^{57}$ Gesell, Infancy and Human Growth, p. 57; and Notes of Staff Meeting, 5 Nov. 1926, Gesell Papers, Box 129.

${ }^{58}$ Notes of Staff Meeting, 12 Nov. 1926, 8 Oct. 1927, Gesell Papers, Box 129. For "role-taking capacities" of unruly subjects see Morawski, "Scientific Selves" (cit. n. 21), p. 141. For performing children in the dome see Analysis of Shirley Hartigan, Gesell Papers, Box 121; and CCHP, Arnold Gesell, raw footage of research films, accessed through David Baker, "Arnold Gesell's Films of Infant and Child Development," Databrary, 2014, https://doi.org/10.17910/B7.70 (accessed 28 July 2020). 
disguised, muffled cameras and the spectators - and posed and acted accordingly, despite all the efforts made to ensure their unaffected normal natural behavior and secure uniform photographs for developmental seriation.

The minutes of staff meetings during the two-year period of designing the photographic laboratory show how the Psycho-Clinic team came to realize that they had to think in photographic sequences. They began to conceive of photography, research procedures, and development as a single unit. That, in turn, influenced their perception of behavior-mind relations. One challenge of creating sequences was to anticipate directions of study for research on topics not yet known and formulate the connected examination procedure that could be repeated in every examining session. In the beginning, Gesell and his team discussed their research topics "in terms of classification of photographs," imagining an inventory indicating "points and dates of origin" of different behavior traits. But soon they noticed that topical filing didn't bring them any closer to understanding development. Instead, Gesell motivated his team to "visualize the problem in more experimental terms": they would need a physical setting with considerable uniformity and examinations with "lines of continuity uniting them." This furnished material for a "photographic sequence record" and made "the photographs more significant from the genetic or growth point of view." ${ }^{\prime \prime}$

To guarantee the same photographic sequences throughout the child's career as a research subject, the presentation of the test toy material remained in the same order in every examination. The sequences were meticulously tuned, matching different age levels in duration and complexity but still operating with the same play objects and covering the same behavior situations in categories such as locomotion, language, and personal-social behavior, from one month up to two years of age. The idea was to inject "a superficially artificial element into the examinations," which meant introducing every toy task at an age "when the child is still indifferent" to the play object and observing the child's change in response to the object from one examination session to the next. This would elicit the whole developmental reaction transition. ${ }^{60}$ Gesell's contemporaries questioned the value of a method based on reactions to items with which the infants were already familiar owing to test situations that were repeated monthly, but Gesell discovered no correlation between the change in reaction and learning by repetition in his control surveys. He believed that sticking too closely to learning theories obscured thinking about development. Rather, he stated at a staff meeting that because of the "physical uniformity the behavior or reaction differences will be more significant and will have more of a genetic suggestion." ${ }^{11}$

This "genetic" research was aimed at revealing more about the genesis and growth of human minds. Gesell took the test situation "posture" as an example in discussing the genetic approach at staff meetings. He wanted the continuity of systematic photography to show behavior series with changes in posture sequences, and so he positioned even small infants in every position of prone, sitting, and standing posture (see Figure 5). A postural sequence, however, was not only a sequence of static positions: rather, every posture position was itself a sequence of behavior moments. Thinking in terms of photographic sequences led to a different, more dynamic postural concept. "When the term posture is used the ordinary connotation is static," Gesell noted to his team. But "in our context we use the term dynamically and in terms of control." Postural control

\footnotetext{
${ }^{59}$ Notes of Staff Meeting, 22 Oct. 1926, 29 Oct. 1926, Gesell Papers, Box 129.

${ }^{60}$ Notes of Staff Meeting, 24 Jan. 1927, 29 Oct. 1926, ibid.; and Gesell and Thompson, Infant Behavior (cit. n. 1).

${ }^{61}$ Notes of Staff Meeting, 29 Oct. 1926, Gesell Papers, Box 129. The developmental psychologist John Anderson noted that in developmental psychology "one is never sure whether the particular phenomena studied are the result of development or the result of the introduction of artificial conditions so essential to experiment": Anderson, "Methods of Child Psychology" (cit. n. 23), p. 7. On the relation of learning, ability, and growth see, e.g., Gesell, Infancy and Human Growth, pp. 13-14; and Arnold Gesell, Learning and Growth [film] (New York: Erpi Picture Consultants, 1934).
} 

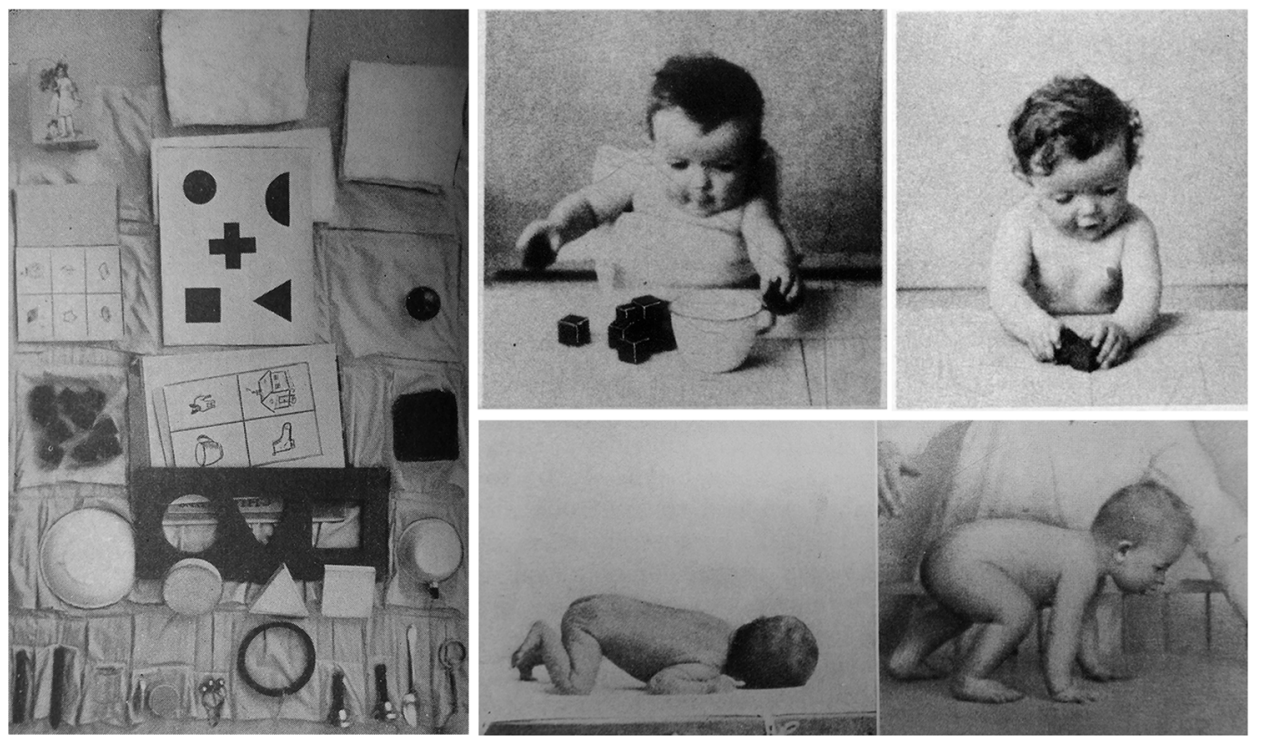

Figure 5. Left: Examination bag with test toys. Image: Arnold Gesell, Infancy and Human Growth (New York: Macmillan, 1928), p. 54. Top, center, and right: Cube behavior of the same girl at thirtysix and forty-eight weeks. Image: Arnold Gesell, An Atlas of Infant Behavior, 2 vols. (New Haven, Conn.: Yale Univ. Press, 1934), Vol. 1: Normative Series, pp. 29, 303; reproduced with kind permission of the Yale Child Study Center. Bottom, center, and right: Illustration of the continuity of prone examination at four and fifty-two weeks. Image: Arnold Gesell and Helen Thompson, Infant Behavior: Its Genesis and Growth (New York: McGraw-Hill, 1934), p. 61.

involved problems of motor coordination - or, rather, neuromuscular discoordination and immaturity: "The stills would give us the attitude and the stance, but the motion picture will give the active side. Posture is not something static, and can only be had completely through the motion picture." ${ }^{2}$

The film focus on sequenced body movements as a key concept for the investigation of mental development had broader epistemological ramifications. "We are going to think less and less of the mind in a conventional sense. We are going to think of body adjustments to situations," Gesell concluded from their photographic laboratory work, explicating a concept of behavior as concerning the entire individual organism that "even adult psychology is coming down to." With this kind of mind-behavior relation, the danger of "analytically projecting the adult conception" of a behavior value onto the lower levels of age and thereby making too much of an "entity" of it - an error "even Watson has approached" - was averted. Photographed behavior could be brought into "genetic sequence." By seeing mental development through filmic behavior sequences, even "very primitive and simple reactions of the infant" became "comparable to those of the older child and adult." ${ }^{63}$ Photographic sequences suggested that the contested "principle of unrestricted concomitance between life and so-called mind" prevailed. ${ }^{64}$ The mind's

\footnotetext{
${ }^{62}$ Notes of Staff Meeting, 12 Nov. 1926, Gesell Papers, Box 129.

${ }^{63}$ Notes of Staff Meeting, 12 Nov. 1926, 22 Oct. 1926, 12 Nov. 1926, ibid.

${ }^{64}$ Notes of Staff Meeting, 5 Nov. 1926, ibid. Gesell was very likely referring to a discussion of evolution and the inception of mind in C. Lloyd Morgan, Life, Mind, and Spirit (London: Williams \& Norgate, 1926).
} 
development, whether in evolution or in every individual, proceeded with continuity from the beginning of life.

Baby Teddy worked with the toy tests in front of human and photographic observers every four weeks for the first year, with his last follow-up visit ten years later. His visits delivered experimentally standardized behavior captured in different types of records: preliminary maturity ratings, test records such as the child's drawings, anthropometric measurements, parent interviews and home observations, stenographic narrative records of the continuous commentary of the examiner during an examination, and thirty-three reels of film records. All were data of development, albeit recorded in different forms. ${ }^{65}$ Developmental knowledge was inscribed into these data both by the procedures of recording and by the materiality of the record. The distinctive form of the record, as historical studies of science and media have shown, was decisive for the knowledge that was in the making. ${ }^{66}$ Every data form had different qualities and produced a different kind of child development, even if the behavior that was being recorded was the same.

The film records, the photographic data, preserved and recreated the vivid naturalness of a whole, individual child who could be stored over time, duplicated, transported, compared, and shared. Gesell later pointed out that the film records were so valuable that "the major energies of the clinic are focused upon the study and analysis of these records." He and the staff members found them superior to direct contact with the actual children owing to their analytical potential and the control of the observer, who was not as affected by a true-to-life film child as by a real-life baby ${ }^{67}$ With the adoption of these naturalistic film data into their research routines, the initial discrimination of behavioral data, film record, and child faded. Teddy and the other babies turned into photographic data children.

During the exploratory period in 1927, data child Teddy helped his researchers devise techniques and formulate preliminary norms, which would later build the foundation for further developmental research and the ubiquitous developmental norms. Prior to the use of film, the behavior discrepancies between two living infants had made visible developmental increments that became benchmarks for rough normative formulations "in which a living subject instead of a calculated norm becomes the standard of measurement." The film children also offered opportunities for various types of study based on lifelike comparisons of individuals. Although staff member Halverson, the experimental psychologist, would have preferred to use film for a quantitative study of as many children and to amass as much developmental data as possible, Gesell persisted in a more qualitative and comparative method. With the film sequences showing the "dynamic shift" of the individual, Gesell wanted his researchers to study "qualitative aspects" related to "intensity, and vividness and depth of behavior." ${ }^{68}$ Film further intensified the comparative approach. The film children could now be compared to each other with greater precision. Moreover, a child could be compared to herself.

Juxtaposing a child with her former and future selves was an analytical breakthrough. The Psycho-Clinic team used two projectors for replaying and repeating simultaneously the same behavior episodes of a child at two different age levels, with novel controlling cranks to "freeze" behavior moments in single frames. The purpose of this comparison was "to describe what the child is doing at this age in terms of his previous behavior" and to discern formerly unrecognized earlier behavior by going back from the present age. Seeing development backward and

\footnotetext{
${ }^{65}$ For Teddy's data see CCHP, Arnold Gesell film collection, index card catalogue of the Photographic Research Library. For the different data types see Gesell and Thompson, Infant Behavior (cit. n. 1), pp. 15-17.

${ }^{66}$ See Christoph Hoffmann, "Festhalten, Bereitstellen: Verfahren der Aufzeichnung," in Daten sichern, ed. Hoffmann (cit. n. 13), pp. 7-20.

${ }^{67}$ Lawrence K. Frank, Memorandum: Interview with Gesell, 9 Dec. 1932, GEB, Series 1.4, Box 636, Folder 6610.

${ }^{68}$ Gesell, Infancy and Human Growth, p. 101; and Notes of Staff Meeting, 1 Feb. 1927, Gesell Papers, Box 129.
} 
cut into single frames, the researchers could break a child's behavior into "discrete 'entities'" with lines of continuity previously invisible and combine them into "constellations and groupings of prevailing characteristics." ${ }^{69}$ This method of "dissecting" data children, later enhanced by an analytical film desk Halverson had designed to accommodate the technique of "cinemanalysis," resembled the earlier methods and developmental narratives in embryology. ${ }^{70}$

In contrast to cross-sectional models of developmental stages, this developmental psychology was based on examinations of individual developmental processes. Analyzing the film children, Gesell and his team discovered ongoing individual constellations of behavior traits that Gesell declared to be the basic structure of "individual differentiation." Whereas a behaviorist like Watson claimed that he could take any baby and build any type of man, Gesell's theoretical conclusion from the construction period of the photographic dome was that "distinctive human and individual traits come not by way of addition to a common substructure but are laid down in the substructure itself." ${ }^{\text {"1 }}$ Behavior grew gradually from an individual original core, as did the infant's mind.

Film technology and data created a conceptual temporality for tracking the trajectory of individual developmental change. The Photographic Research Library of the Psycho-Clinic linked the film records with the multitude of other data forms and organized their use in an archive of behavior and development, practicing child development research as a science of the archive. Just as the "transcendence of time, of past, present, and future merged in the archives," the past and future of a child in Gesell's Photographic Research Library were "absorbed into the present" and turned descriptions of behavior patterns into predictions of development. ${ }^{72}$ Concurrently, this step converted developmental research based on the development of individuals into a science of prediction and control that was important for society's future development. The individual film children, however, provoked an understanding of the normal child different from the Progressives' use of the child as a tool for social control. For Gesell, the innate growth capacity and individual differentiation he saw through photographic sequences were both causes for a normative developmental order and "causes for developmental variety." The "reciprocal" relation between "Normative + Genetic" that he posited in his research also had implications for child development outside the laboratory. The individual capacity for mental development, he argued, could be fostered but not changed. Human variety should not be constrained but respected, whether in an adult or a newborn child. ${ }^{73}$ Infants didn't merely have minds: they had their very own minds.

\section{DEVELOPING NORMALITY: PRODUCING FILM, INDIVIDUAL BABIES, AND NORMS}

The theory that infants had individual minds that were continuously developing, and the conclusion that the normal was tied to individuality, originated in the construction period of the

\footnotetext{
${ }^{69}$ Notes of Staff Meeting, 6 Oct. 1927, 1 Feb. 1927, Gesell Papers, Box 129; and Handwritten Note for Staff Meeting, 7 Oct. 1927, ibid.

${ }^{70}$ Gesell, "Cinemanalysis" (cit. n. 36). For more on this method see Curtis, "Tangible as Tissue'” (cit. n. 7).

${ }^{71}$ Notes of Staff Meeting, 1 Feb. 1927, Gesell Papers, Box 129; and Gesell, Infancy and Human Growth, p. 371. For Watson's opposing views see John B. Watson and Rosalie Rayner Watson, Psychological Care of Infant and Child (New York: Norton, 1928). ${ }^{72}$ For the organization of the photographic library see CCHP, Arnold Gesell film collection, index card catalogue of the Photographic Research Library. On cinematographic time absorption see Gesell, Infancy and Human Growth, p. 70. On the "transcendence of time" in the archive see Lorraine Daston, "Introduction: Third Nature," in Science in the Archives: Pasts, Presents, Futures, ed. Daston (Chicago: Univ. Chicago Press, 2017), pp. 1-16, on p. 12.

${ }^{73}$ Handwritten Note for Staff Meeting, 7 Oct. 1927, Gesell Papers, Box 129. For the theoretical conclusions and their ideological consequences, both of which were linked to Gesell's attempts to resolve the controversy over the influence of heredity and environment, see Gesell, Infancy and Human Growth, pp. 355-378.
} 
photographic dome and the developing techniques of data and film production. The photographic program, although different from prevailing methods of measurement, had started with common psychological questions about individual differences. A few months later, Gesell became concerned about not being able to "avoid comparing individual differences" in defining increments of development owing to the imperfections of his provisional norms. Three years later, he began to write about the individual in infancy. ${ }^{74}$ Comparing a child's individual sequences with her own younger and older self, Gesell concluded that consistent distinctive behavior patterns registered by the cinematic camera demonstrated "the existence of individuality even in infancy." Individual case studies were selective - and even more so when conducted by means of film production. The Yale researchers argued that one "happily selected" infant that they described as normatively representative "might be as good as a hundred" or, indeed, "be much better than a hundred poorly selected cases." To save on expensive film material, the recording of only the most uniform and typical examination situations, as well as the "systematic and selective" inventory of the photographic library, added to this selective construction of normality. ${ }^{75}$

In the production process for the photographic sequence records, the developmental norms of the Psycho-Clinic became "all but infinite in number," in both their progressing continuity and their individual variety. Although the normal babies and their behavior moments were very carefully curated, the Psycho-Clinic team discovered individual deviations from the norms within their group of 107 children designated normal. Norms of development were an "effort to catch or characterize certain fundamental identities which underlie human growth," Gesell explained, but "one true norm" was always a "host of other potential norms." A normal child, this theory of norms postulated, developed along a generally formulated order according to that particular child's innate capacity for growth and development-that is, in a formulaic succession of that child's own normal states. ${ }^{76}$ In summary, a mental growth course that was, in itself, consistent and predictable expressed developmental normality; the variety of these normalities expressed individuality. The result was the perception of development as the normal state and a conception of the normal in terms of individualized consistent development.

A baby who could be her own norm had theoretical, educational, and political dimensions. Although it was a technology of uniformity and control, the photographic dome provided insight into child development that was associated with ideas of liberty, self-regulation, and individuality. The Psycho-Clinic team noticed that parents who watched the procedures behind the one-way-vision screen developed "an interest in observing the child's activity without stepping in" and thus "the habit of refraining from interfering." Through visual technology, the researchers both generated the theory of individual innate development and incorporated this view on development into education. They hoped that parents and child workers would understand the characteristics of development and learn a more liberal way of handling their children "naturally thru observation." Under the shadow of fascism and war, they maintained that understanding development was key to recognizing and respecting the individual child. This would lead to less rigid instructions and, in turn, avert constraints on a child's individual nature. A "philosophy of individual development" in family and society affirmed-in contrast to a "totalitarian "Kultur" - the dignity of the individual and had "much in common with the

\footnotetext{
${ }^{74}$ Proposal for a Developmental Research Clinic, LSRM, Series 3.5, Box 47, Folder 492; Notes of Staff Meeting, 19 Nov. 1926 , Gesell Papers, Box 129; and Arnold Gesell, "The Individual in Infancy," in The Foundations of Experimental Psychology, ed. Carl Murchison (Worcester, Mass.: Clark Univ. Press, 1929), pp. 628-660.

${ }^{75}$ Gesell, Atlas of Infant Behavior (cit. n. 34), Vol. 1, p. 11; Gesell and Thompson, Infant Behavior (cit. n. 1), p. 10; and Notes of Staff Meeting, 22 Oct. 1926, Gesell Papers, Box 129.

${ }^{76}$ Gesell, Infancy and Human Growth, p. 125.
} 
ideology of democracy." 77 The view of individual differences and control that Gesell held before the beginning of the dome construction yielded to ideas of individuality, a developmental normal, and a variety essential for democracy.

In the laboratory of the Yale Psycho-Clinic, film and photography served as an individualizing research and communication technology. Rather than applying statistical calculations and numerical scales, the photographic dome brought individual babies and their individual development to the fore. The normal constructed through the dome's visual technology showed none of the quantitative relations to the pathological that most other methods of psychological measurement implied. This approach to norms and the normal is evocative of the notion of the individual normal elaborated by the philosopher and physician Georges Canguilhem during World War II. Norms are not a rigid collective average but have individual flexibility, Canguilhem postulated. The normal is not a statistical reality but has to be determined in relation to individual conditions by successively considering the same individual. ${ }^{78}$ Despite these conceptual congruencies, Gesell questioned the normal only in the context of psychology and education. The main concern of his scientific and philosophical consideration was, after all, human development. Norms were an empirical necessity and the normal the conceptual framing that made it possible to understand and utilize the law of mental development. Normality was the result.

In the history of normality's development through the developmental norms, the photographic research - quite ironically-bolstered the very concept it opposed. The photographic dome was a technology explicitly designed to prevent the "danger" and "misuse" of overly standardized and statistical norms. ${ }^{79}$ Film technology produced lifelike data and constituted babies as individuals with minds of their own. However, once the film material left the laboratory, the second function of film production - to enable intervention - turned these very qualities of individuality that the film had presented as a research technology into the fallacy of visual media that effected normalization. When the developmental norms entered the public realm, mothers could be found "matching" their children "with Gesell" in a desire to optimize those children according to the ideal normal they saw represented by the true-to-life children of the Psycho-Clinic. Child workers, on the other hand, applied the developmental norms like numerical scales and made rigid assessments of normality by measuring the deviation of a baby's developmental potential from the norm. Although Gesell tried to include descriptions and visual traces of the photographic dome and the film production in the published films and picture series, the work of conceptualization and technological construction involved in producing normal development ultimately disappeared. ${ }^{80}$ The normal baby who traveled from the laboratory into public spaces where she showcased her development appeared to be a simple copy of life and, thus, a standard given by nature.

Visual technology was the critical factor in the formation of these pervasive developmental norms. More than just facilitating the popular distribution of research results or providing a scientific method, the material aspects of the photographic dome and film production, I have argued, constituted the developmental concept and the idea of the normal behind the norms.

\footnotetext{
${ }^{77}$ Notes of Staff Meeting, 23 Mar. 1928, Gesell Papers, Box 129; and Arnold Gesell and Frances Lillian Ilg, Infant and Child in the Culture of Today: The Guidance of Development in Home and Nursery School (New York: Harper, 1943), pp. x, 9, 363.

${ }^{78}$ Canguilhem, Normal and the Pathological (cit. n. 2).

${ }^{79}$ Notes of Staff Meeting, 3 Dec. 1926, Gesell Papers, Box 129.

${ }^{80}$ Joseph Brennemann, "The Menace of Psychiatry," American Journal of Diseases of Children, 1931, 42:376-402; and Ellen Herman, Kinship by Design: A History of Adoption in the Modern United States (Chicago: Univ. Chicago Press, 2008), p. 168. For a similar effect in embryology see Nick Hopwood, "Producing Development: The Anatomy of Human Embryos and the Norms of Wilhelm His," Bulletin of the History of Medicine, 2000, 74:29-79.
} 
Producing data for scientific research while also enabling intervention, film technology defined the understandings of the normal child for scientific research, as well as in public and private life. Although the photographic dome and film production brought the individuality of every child and thereby a democratic variety of norms to light, the recorded children of the Yale Psycho-Clinic eventually reinforced the very system of normality they had been created to challenge. The developmental norms that originated in the photographic laboratory evoked both the normative effect of enforcing "conformity to a fixed standard" and the individuating effect of "measuring the distance between an individual and the norm," which has been identified as the double movement of modern normalization. ${ }^{81}$ The initial period of the photographic research program - the construction of the dome examined here-reinforced the development of a normality characteristic for the twentieth century. Visual technologies in science and their simultaneous data and media production, as shown in this essay, are an analytical focus that can reveal the relation between a scientific theory and highly popularized knowledge about human nature-a relationship on which the era's ideology of normalcy was built.

${ }^{81}$ Cryle and Stephens, Normality (cit. n. 2), pp. 353, 8. 